Article

\title{
Using Edible Plant and Lightweight Expanded Clay Aggregate (LECA) to Strengthen the Thermal Performance of Extensive Green Roofs in Subtropical Urban Areas
}

\author{
Yi-Yu Huang * and Tien-Jih Ma \\ Department of Landscape Architecture, Tunghai University, 40704 Taichung, Taiwan; jackie82430@gmail.com \\ * Correspondence: yyhuang@thu.edu.tw
}

Received: 17 December 2018; Accepted: 25 January 2019; Published: 29 January 2019

check for updates

\begin{abstract}
Gazing at natural landscapes and participating in agricultural activities can elicit psychophysiological restoration. However, most buildings are constructed merely to meet the minimum legal requirements for structure weight load. Extensive green roofs consisting of vegetables and a lightweight growth medium can be designed to provide not only passive-cooling effects on bare rooftops, but also to convert idle rooftops into temporary retreats for stressed individuals. The purpose of this study is to both measure the surface temperature reduction and heat amplitude reduction of a bare rooftop using the extensive green roofs containing a lightweight expanded clay aggregate (LECA) and Ipomoea batata as well as conduct a weight-reduction-and-cost analysis to measure the weight loss of the extensive green roofs incurred through LECA replacement. A four-stage field experiment was performed on the flat rooftop of a dormitory in a subtropical climate during summer. The results indicated that roofs with Ipomoea batata had a significantly higher passive-cooling effect than did roofs without Ipomoea batata. The roofs with $10 \%-40 \%$ LECA exhibited a slightly higher passive-cooling effect than did roofs with conventional garden soil. At a slightly different average air temperature $\left(0.56{ }^{\circ} \mathrm{C}\right.$; i.e., $32.04{ }^{\circ} \mathrm{C}$ minus $\left.31.48{ }^{\circ} \mathrm{C}\right)$, the combined effects of LECA and Ipomoea batata helped to significantly reduce the average temperature of the bare rooftop by an additional $10.19^{\circ} \mathrm{C}$, namely, temperature reduction of the bare rooftop increased from $9.54{ }^{\circ} \mathrm{C}$ under a roof with $0 \%$ LECA and without plants in the second stage to $19.73^{\circ} \mathrm{C}$ under a roof with $10 \%$ LECA and with plants in the fourth stage.
\end{abstract}

Keywords: Ipomoea batatas; lightweight expanded clay aggregate (LECA), thermal performance; extensive green roof; subtropical climate

\section{Introduction}

In modern urban societies, stressful lifestyles have increasingly driven humans to seek temporary stress relief, and stressful lifestyles are well known as the major causes for many physical and psychological illnesses [1], including anxiety, depression, insomnia, burnout syndrome, as well as gastroenterological, cardiovascular, neurological, and immunological diseases [2,3]. Consequently, stress management should receive significant research attention in the interests of public health.

Compared with urban environments, natural environments are generally associated with positive health effects $[4,5]$. When city dwellers have insufficient time to relax in a city park, a rooftop garden may be an ideal alternative site for a temporary daily retreat. More than three decades ago, Kaplan [4] and Ulrich [5] emphasized the importance of natural environment and landscapes in reducing stress. More recent findings have demonstrated that even short visual encounters with natural settings can elicit significant psychophysiological restoration within 3-5 min at most or as 
quickly as $20 \mathrm{~s}$ [6-8]. Furthermore, with the exception of passive gazing, more benefits could be elicited from actively participating in horticultural activities because they invoke reminiscence of meaningful past experiences, spiritual healing, and stimulation of five senses [9].

Consequently, rather than sedum or crassulacean acid metabolisum (CAM) plants [10], which have frequently been used in studies to assess the thermal performance of extensive green roofs because of their endurance in arid and windy rooftop environment, we decided to use vegetables for our extensive green roofs. The advantages of using vegetables rather than sedum or CAM plants, which usually have low leaf-area indexes (LAIs), for extensive green roofs include high LAI, edibility, low carbon dioxide emissions, and provision of horticultural activity.

LAI, measured as a ratio of total one-sided area of photosynthetic tissue to the ground-surface area below them, represents the area of leaf coverage and defines the latent heat loss of an extensive green roof [11]. The higher the LAI, the greater the effects of shading, insulation, and evapotranspiration of the extensive green-roof plant layer, which contribute to significant reduction in rooftop surface temperature [11]. Moreover, the use of edible plants can be considered an implementation of the Edible Landscape Initiatives, which reintroduce food into urban and rural landscapes to increase local food security. If numerous empty and idle rooftops [12] can be converted into city farms, then these farms can be expected to significantly reduce carbon dioxide emissions because less food would require transportation from rural areas to cities, and our neighborhood microclimate and human thermal comfort can also be improved [13].

Vegetables suitable for rooftop planting in subtropical climates in Taiwan include Rosmarinus officinalis, Abelmoschus esculentus, Ipomoea batatas, Gynura bicolor, Perilla frutescens, Capsicum annuum, Ocimum basilicum, Solanum melongena, Phaseolus vulgaris, and Luffa cylindrical [14]. After careful consideration, Ipomoea batatas was selected because of its resistant to wind, sun, and drought as well as its low maintenance, high LAI, easy obtainment of $100 \%$ plant-bed coverage, year-round harvesting, high nutrition, and popularity.

To reduce construction costs, the structural loads of most buildings in Taiwan frequently only barely meet minimum requirements. According to architectural regulations, the live load of a building-that is, the static and constant forces to which a building is subjected for an extended time period-is $200.00 \mathrm{~kg} / \mathrm{m}^{2}$ [15]. Thus, lightweight green-roof systems are recommended in Taiwan. Quality growth medium for extensive green roofs should drain well, demonstrate excellent water-holding and nutrition-holding capabilities, provide sufficient support for plant roots in shallow soil depths of $10-20 \mathrm{~cm}$, and be lightweight. A common growth medium utilized for extensive green roofs is a mixture of sandy loam, organic matter, and a lightweight growth medium. The most common organic matters are compost and peat, and the most common lightweight growth medium are perlite, zeolite, pumice and lightweight expanded clay aggregate (LECA) [16-21]. A common formula used for lightweight growth medium is $15-30 \%$ sandy loam, 20-30\% organic matter, and 50-70\% lightweight growth medium [16-21].

According to field measurements, LECA has a potentially superb thermal reduction performance. Lin and Lin [22] compared the thermal reduction performance of four different types of growth mediums: sand; sand and white-charcoal debris (5:1); peat moss, vermiculite, and burned clay (1:1:1); and burned reservoir sludge mixed with rice hull, baked at $900{ }^{\circ} \mathrm{C}$ (which is similar to LECA). They compared the performance of these mediums with four CAM plants in the tropical climate of Taiwan and discovered that the burned reservoir sludge exhibited the greatest reduction in heat amplitude $(88.8 \%)$ and exhibited the second best bare-rooftop temperature reduction. Although sand was the optimal growth medium for bare-rooftop temperature reduction, its weight poses potential problems for the weight load of building structures, and sand mining causes numerous environmental problems, including land erosion and habitat destruction [22]. Burned reservoir sludge, an efficient tool for clearing mud build-up at the bottom of reservoirs to prolong reservoir lifespans, also demonstrated an excellent temperature-reduction performance on the bare rooftop because of its ability to hold water and air as a mesoporous material. Because water content can effectively slow the rise in temperature 
of growth mediums during the daytime, and air content can increase the heat insulation of growth mediums, porous growth mediums can produce superior temperature-reduction effects. Further, great porosity can also invigorate plant roots by increasing air content. By comparing porous (pebbles and silica sand) and nonporous (volcanic ash and siliceous shale) materials of various particle sizes, Wanphen and Nagano [23] demonstrated that porous materials can more effectively lower the surface temperature of bare rooftops than can nonporous materials. The reason for this is that mesoporous materials contain a high volume of pores of an appropriate size to hold water during the night and release substantial vapor during the day, resulting in the release of considerable latent heat and more effective rooftop surface temperature reduction. Sutcu reported that the thermal conductivity of porous brick containing 10\% expanded vermiculite was 32\% lower than that of conventional brick (a reduction from 0.96 to $0.65 \mathrm{~W} / \mathrm{m}^{2} \mathrm{~K}$ ) and thus could be used as an effective insulating material for combating the high ambient temperature [24]. Consequently, we selected LECA as the lightweight growth medium because, as a mesoporous material, its porosity enables it to hold water, air, and nutrients while also draining effectively; furthermore, LECA does not rot, which means that it provides excellent support to plants in shallow depths, and it is inexpensive, widely available in Taiwan, and environmentally friendly.

The present study aimed to fulfill the following objectives by conducting a four-stage experiment during the hottest months in a subtropical climate:

1. Investigate the depth of the growth medium;

2. Investigate the proportion of LECA in the growth medium;

3. Investigate the placement of LECA in the growth medium;

4. Investigate how adding Ipomoea batatas affects the thermal performance of extensive green roofs.

5. Conduct a weight-reduction-and-cost analysis of extensive LECA roofs.

\section{Materials and Methods}

\subsection{Experiment Site}

Field measurements were conducted on the rooftop of a multistory student dormitory in a university $\left(24^{\circ} 10^{\prime} 54.0^{\prime \prime} \mathrm{N} 120^{\circ} 36^{\prime} 04.3^{\prime \prime} \mathrm{E}\right)$ located in the metropolitan area of Taichung, the third largest city in Taiwan. According to the East Asia map of the Koppen climate classification, the site is located in a warm oceanic climate/humid subtropical climate (Cfa) zone with the lowest monthly average temperature of $16.8^{\circ} \mathrm{C}$ in January and highest temperature of $30.1^{\circ} \mathrm{C}$ in July for the years 2014-2016; additionally, the lowest monthly relative humidity is $76.0 \%$ in January, and the highest relative humidity is $83.7 \%$ in May (Figure 1) [25]. Figure 2 shows the floor plans of the fourth and fifth floors (experiment site) and the experimental setup.

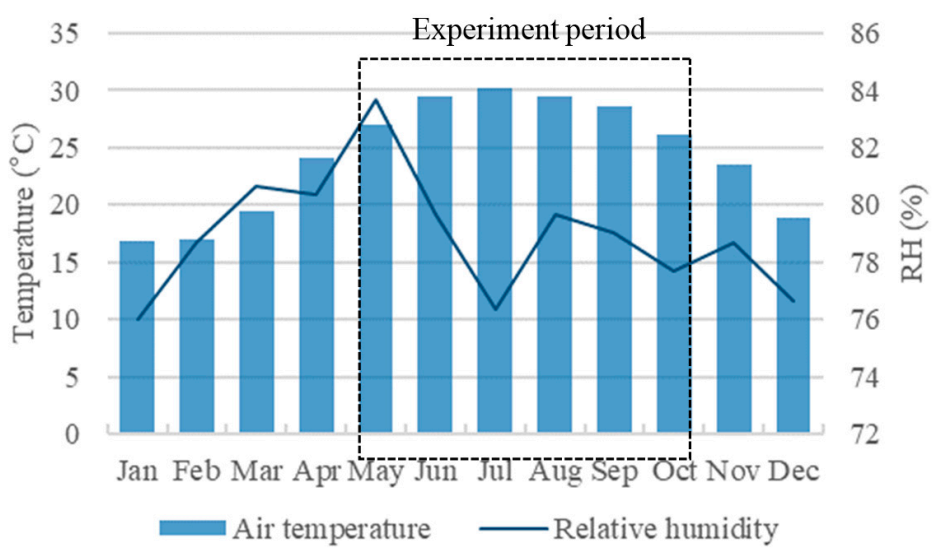

Figure 1. Average temperature and relative humidity observed at the nearest weather station (Long-Jing station), Taichung, 2014-2016. 


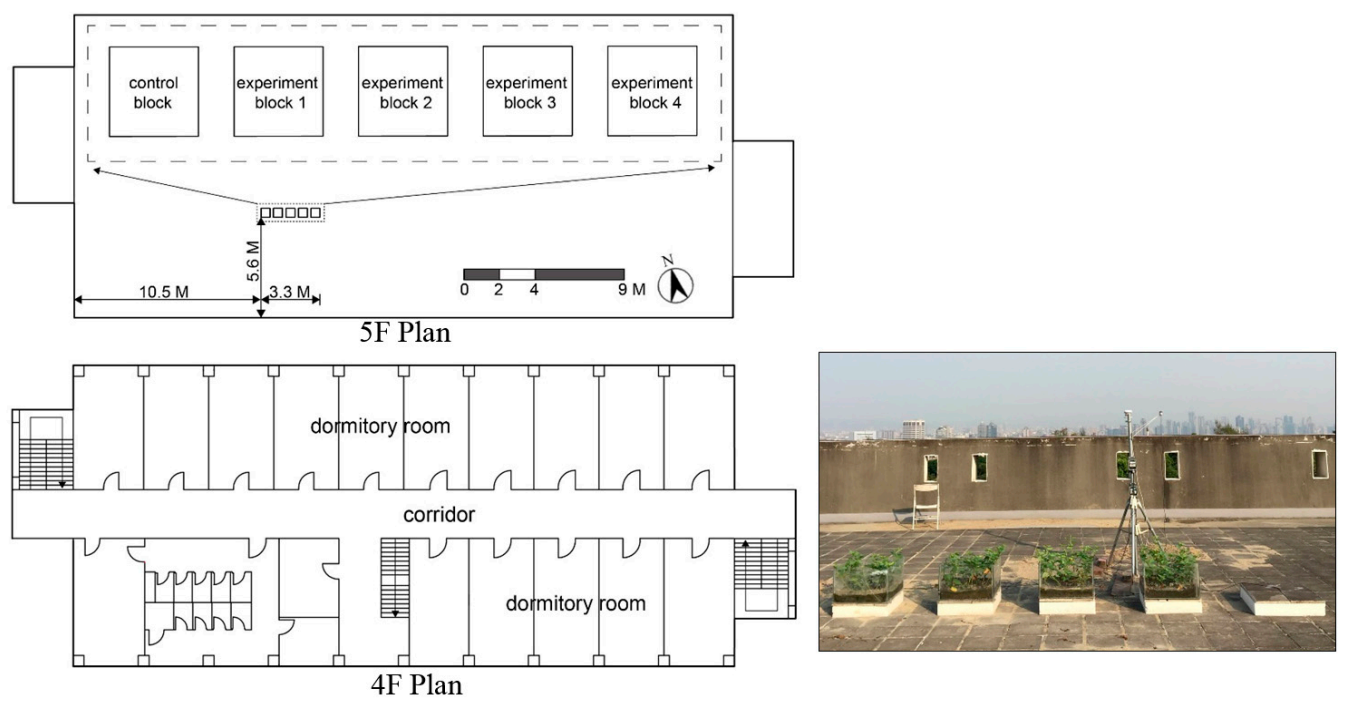

Figure 2. Floor plans of the fourth (lower left) and fifth (upper left) floors. Five blocks on the fifth floor served as experimental blocks (upper left). Experiment site and experimental setup (right).

\subsection{Description of Plant Material and Growth Medium}

To obtain favorable thermal benefits of the extensive green roof and to yield a year-round food supply, Ipomoea batatas (sweet potato) (Figure 3) was selected as our plant material. Ipomoea batatas thrives in warm weather. Ipomoea batatas leaves are heart-shaped and tend to grow on slender and lengthy stems; the herbaceous perennial vine grows vigorously and easily achieve $100 \%$ coverage, which helps lower the surface temperature and heat amplitude of a bare rooftop. Ipomoea batatas leaves can be harvested throughout the year. A few species of Ipomoea batatas can be used as ornamental ground cover owing to their attractive leaves. Ipomoea batatas can grow abundantly in poor soil. It has a mild and lightly sweet flavor. It is beneficial to the digestive system because of its high dietary fiber content. It helps reduce blood sugar and cholesterol levels, prevent infections, boosts the immune system, and provides a number of benefits to the eyes.
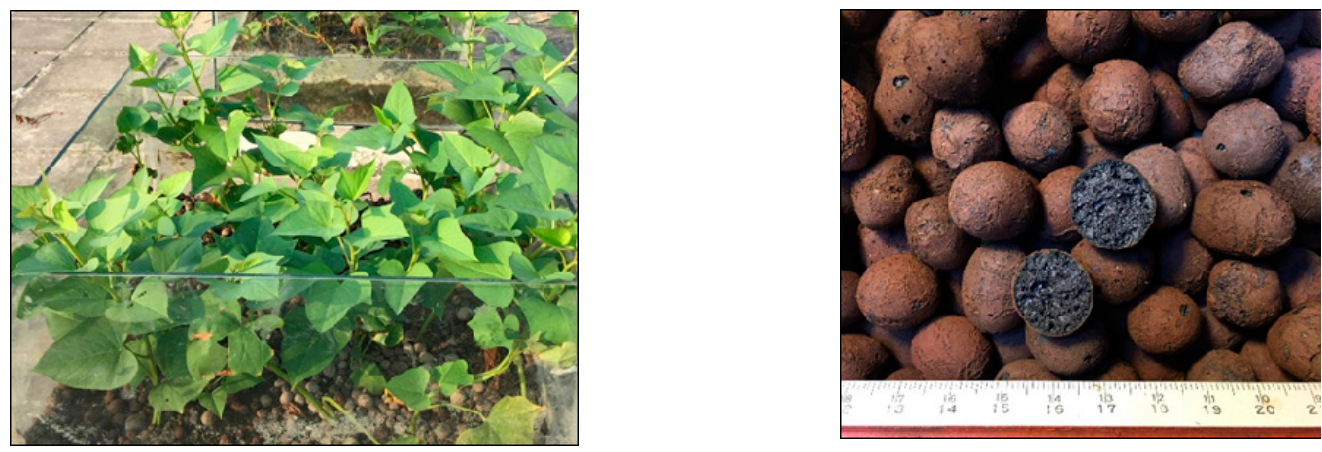

Figure 3. Ipomoea batatas (sweet potato) (left) and LECA (right). Ruler in centimeters (right).

LECA (Figure 3) was selected for mixing with the conventional garden soil, composed of sandy loam:compost $=3: 1$, to reduce the weight load of the building structure [26] and the thermal conductivity of the growth medium, which, in turn, would lead to temperature reduction of the underlying bare rooftop $[23,24]$. Sandy loam is capable of quickly draining excess water, however, it cannot hold significant amount of water and nutrients for plants. The addition of the compost would help increase the the water-holding and nutrient-holding capacity of the soil for plants. The designed conventional garden soil supports the growth of various plants, including vegetables. LECA is a lightweight aggregate produced by baking a mixture of clay powder and saw dust for $7 \mathrm{~h}$ at $1000{ }^{\circ} \mathrm{C}$ [27]. It has a hard ceramic shell, a porous core, and a porous surface [27,28]. LECA is durable, 
stable, and nontoxic $[27,28]$. It can be used to increase the breathability of plant roots, support plants, and prevent soil hardening when it is thoroughly mixed with conventional garden soil or laid at the bottom of the tank [26]. When mixed with cement, LECA can be used to lighten the structure weight load and for thermal insulation and acoustic insulation in buildings [29,30].

\subsection{Experimental Design}

In summer 2017, five $50 \times 50 \times 10 \mathrm{~cm}^{3}$ (length [L] $\times$ width $[\mathrm{W}] \times$ height $[\mathrm{H}]$ ) cement boards capped with ceramic tiles were placed on a flat rooftop to simulate a flat bare roof (Figure 2). Five $50 \times 50 \times 4 \mathrm{~cm}^{3}$ $(\mathrm{L} \times \mathrm{W} \times \mathrm{H})$ Styrofoam boards were placed under the cement boards to block heat conduction from the surrounding bare rooftop. All cement boards were placed close to the middle left of the bare rooftop. They were exposed to direct sunlight at all times, without any shadow interference from surrounding building walls or parapet walls. Four $50 \times 50 \times 30 \mathrm{~cm}^{3}(\mathrm{~L} \times \mathrm{W} \times \mathrm{H})$ glass tanks were placed on top of four cement boards. The glass tanks helped avoid shadow interference from neighboring tanks. One cement board without any tank was exposed directly to the sunlight to simulate a bare rooftop as a control (Figure 2). The experiment tanks were approximately the same size as those used in the studies of Song et al. [31], and Huang et al. [32]. Fifteen dormitory rooms were located directly under the bare rooftop. An extensive green roof system on the bare rooftop would help reduce the temperature of the bedrooms below and hence increase the students' living comfort $[33,34]$. Because heat always flows out of a room and a green roof would act as a heat sink in a green-roofed building during daytime in sunny days, the indoor temperature of a room underneath a green roof is lower than that of a room underneath a common roof during daytime [33]. Based on field measurements, the indoor temperature underneath a green roof was $2^{\circ} \mathrm{C}$ lower than that under a common roof at noon with strong solar radiation $[33,34]$.

The experiment consisted of four stages. The first stage (Figure 4) involved comparing the thermal performance of the extensive roofs when four different depths of the conventional garden soil $(0 \%$ LECA) were employed: 10, 15, 20, and $25 \mathrm{~cm}$. The marginal temperature reduction, determined as the ratio of additional temperature reduction to incremental increase in the depth of the growth medium, was calculated to determine the most efficient depth of growth medium in the second, third, and fourth stages. The second stage (Figure 8) involved comparing the thermal performance when different proportions of LECA- $0 \%$ (conventional garden soil), $10 \%, 40 \%, 70 \%$-were laid at the bottom of the tanks. The third stage (Figure 12) involved investigating which combination (proportion of LECA $\times$ LECA placement) yielded the highest thermal performance without the introduction of Ipomoea batatas. The fourth stage (Figure 16) involved investigating the additional thermal performance after the introduction of Ipomoea batatas have achieved 100\% coverage.
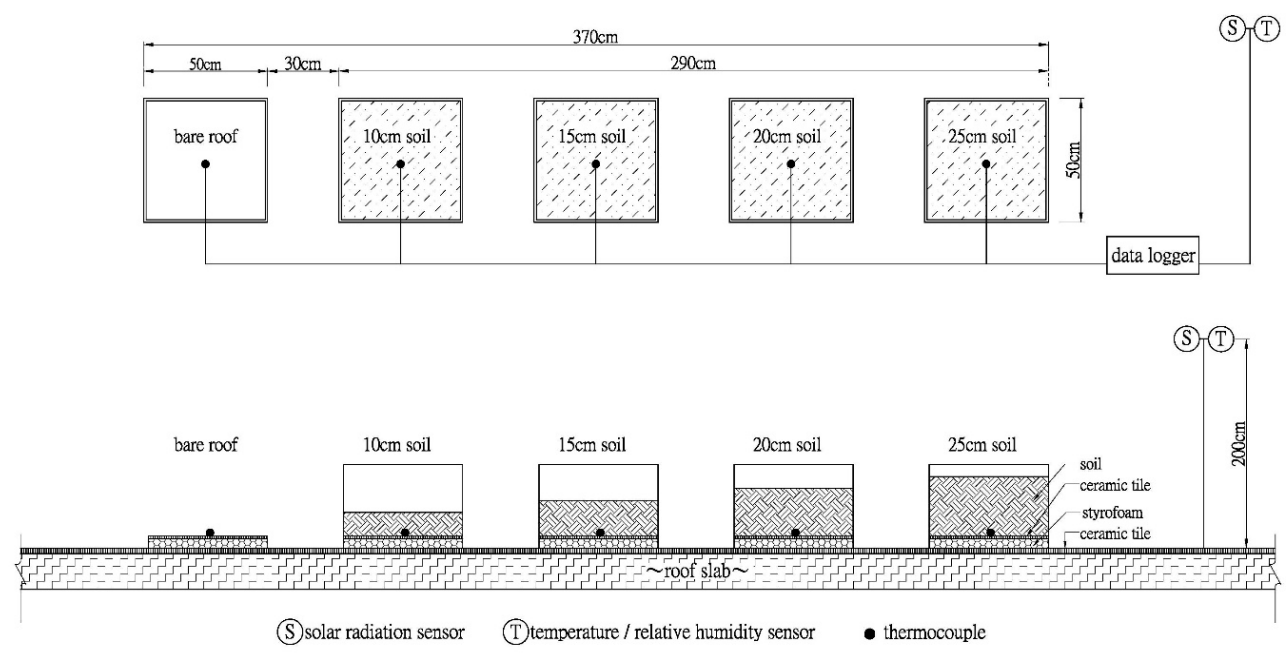

Figure 4. Experimental setup for the first stage. The plan (top) and the elevation (bottom). 


\subsection{Instrument Settings and Measurement Data}

Five measurement points were placed at the bottom center of the extensive roof and at the center of the simulated bare roof. Thermocouples (Onset Computer Corporation) were placed horizontally in close contact with the surface to measure the temperature accurately. Air temperature, relative humidity, and solar radiation were measured at a point $2 \mathrm{~m}$ above the rooftop surface $[35,36]$ and $5.6 \mathrm{~m}$ (shortest distance) away from the parapet walls to prevent any reflective interference from the bare rooftop and parapet walls. A thermal monitoring system comprising three HOBO micro station data loggers (Onset Computer Corporation) was employed to record all measurements at intervals of $10 \mathrm{~min}$. The experiment was conducted in the following four periods: 13-23 May 2017, 14-26 July 2017, 20-27 September 2017 and 28 September-13 October 2017. Please refer to Table 1 for the equipment list.

Table 1. Equipment list.

\begin{tabular}{|c|c|c|c|c|}
\hline Parameters & Equipment Used & Type & Measurement Range & Accuracy \\
\hline Solar radiation & $\begin{array}{l}\text { Solar radiation smart } \\
\text { sensor (Silicon } \\
\text { Pyranometer) }\end{array}$ & S-LIB-M003 & -40 to $75^{\circ} \mathrm{C}$ & $\begin{array}{l} \pm 10 \mathrm{~W} / \mathrm{m}^{2} \text { or } \pm 5 \% \text {, whichever is } \\
\text { greater in sunlight. Additional } \\
\text { temperature induced error } \pm 0.38 \\
\mathrm{~W} / \mathrm{m}^{2} /{ }^{\circ} \mathrm{C} \text { from } 25^{\circ} \mathrm{C}\end{array}$ \\
\hline $\begin{array}{l}\text { Air temperature \& } \\
\text { Relative humidity }\end{array}$ & $\begin{array}{l}\text { 12-bit } \\
\text { Temperature/Relative } \\
\text { humidity smart sensor }\end{array}$ & S-THB-M002 & $\begin{array}{l}\text { Temp: }-40 \text { to } 75^{\circ} \mathrm{C}, \mathrm{RH}: \\
0 \% \text { to } 100 \% \text { at }-40 \text { to } 75{ }^{\circ} \mathrm{C}\end{array}$ & $\begin{array}{l}\text { Temp: }+/-0.21^{\circ} \mathrm{C} \text { from } 0 \text { to } 50{ }^{\circ} \mathrm{C} ; \\
\mathrm{RH}:+/-2.5 \% \text { from } 10 \% \text { to } 90 \% \mathrm{RH} \\
\text { (typical), to a maximum of }+/-3.5 \% \\
\text { including hysteresis at } 25{ }^{\circ} \mathrm{C} ; \\
\text { below } 10 \% \text { and above } 90 \% \\
\pm 5 \% \text { typical }\end{array}$ \\
\hline Temperature & $\begin{array}{l}\text { 12-bit Temperature } \\
\text { smart sensor }\end{array}$ & $\begin{array}{l}\text { S-TMB-M002, } \\
\text { S-TMB-M006 }\end{array}$ & -40 to $75^{\circ} \mathrm{C}$, sensor tip & $< \pm 0.2{ }^{\circ} \mathrm{C}$ from 0 to $50{ }^{\circ} \mathrm{C}$ \\
\hline- & $\begin{array}{l}\text { Hobo micro station } \\
\text { data logger }\end{array}$ & H21-002 & $\begin{array}{l}-20 \text { to } 50{ }^{\circ} \mathrm{C} \text { with alkaline } \\
\text { batteries, }-40 \text { to } 70{ }^{\circ} \mathrm{C} \text { with } \\
\text { lithium batteries }\end{array}$ & $\begin{array}{l}0 \text { to } 2 \text { seconds for the first data point } \\
\text { and } \pm 5 \text { seconds per week at } 25^{\circ} \mathrm{C}\end{array}$ \\
\hline
\end{tabular}

\section{Results and Discussion}

\subsection{Marginal Temperature Reduction When 10, 15, 20, and $25 \mathrm{~cm}$ Conventional Garden Soil and No Plants} Were Used

The first stage (Figure 4) involved comparing the thermal performance of extensive roofs with four different depths of conventional garden soil: 10, 15, 20, and $25 \mathrm{~cm}$. Table 2 shows that the mean air temperature and mean rooftop temperature were 25.15 and $28.44^{\circ} \mathrm{C}$, respectively; the ranges of air temperature and rooftop temperature were $19.37-33.29^{\circ} \mathrm{C}$ and $18.82-52.67{ }^{\circ} \mathrm{C}$, respectively; the maximum solar radiation was $1170.60 \mathrm{~W} / \mathrm{m}^{2}$; the mean relative humidity was $85.54 \%$. A period of $24 \mathrm{~h}$ was selected for further analysis based on the following criteria: high temperature at noon, relatively stable air temperature progression over $24 \mathrm{~h}$, and ample solar radiation with relatively little cloud interference. The date selected was 14-15 May 2017 (Figure 5). The time frame 07:00-14:00 was further selected to compute the passive cooling effects among all extensive roofs for comparisons within and between different stages, because this is the single maximum period of time frame when the passive cooling effects were concurrent across four different stages. According to the experiment results, the passive cooling effects occurred over time frame 07:00-16:00, 07:00-14:00, 07:00-16:00, and 07:00-17:00 for the fist (5 July), second (25 July), third (24 September), and fourth (1 October) stages, respectively. 
Table 2. Weather data for the first stage (13 May 2017 05:59:44 to 23 May 2017 05:49:44).

\begin{tabular}{cc}
\hline First Stage & Value \\
\hline Period of measurement & $13-23$ May 2017 \\
Range of air temperature & $19.37-33.29^{\circ} \mathrm{C}$ \\
Mean air temperature & $25.15^{\circ} \mathrm{C}$ \\
Range of rooftop temperature & $18.82-52.67^{\circ} \mathrm{C}$ \\
Mean rooftop temperature & $28.44^{\circ} \mathrm{C}$ \\
Maximum solar radiation & $1170.60 \mathrm{~W} / \mathrm{m}^{2}$ \\
Mean relative humidity & $85.54 \%$ \\
Date selected for further analysis (marked with dotted box) & $14-15 \mathrm{May} 2017$ \\
\hline
\end{tabular}

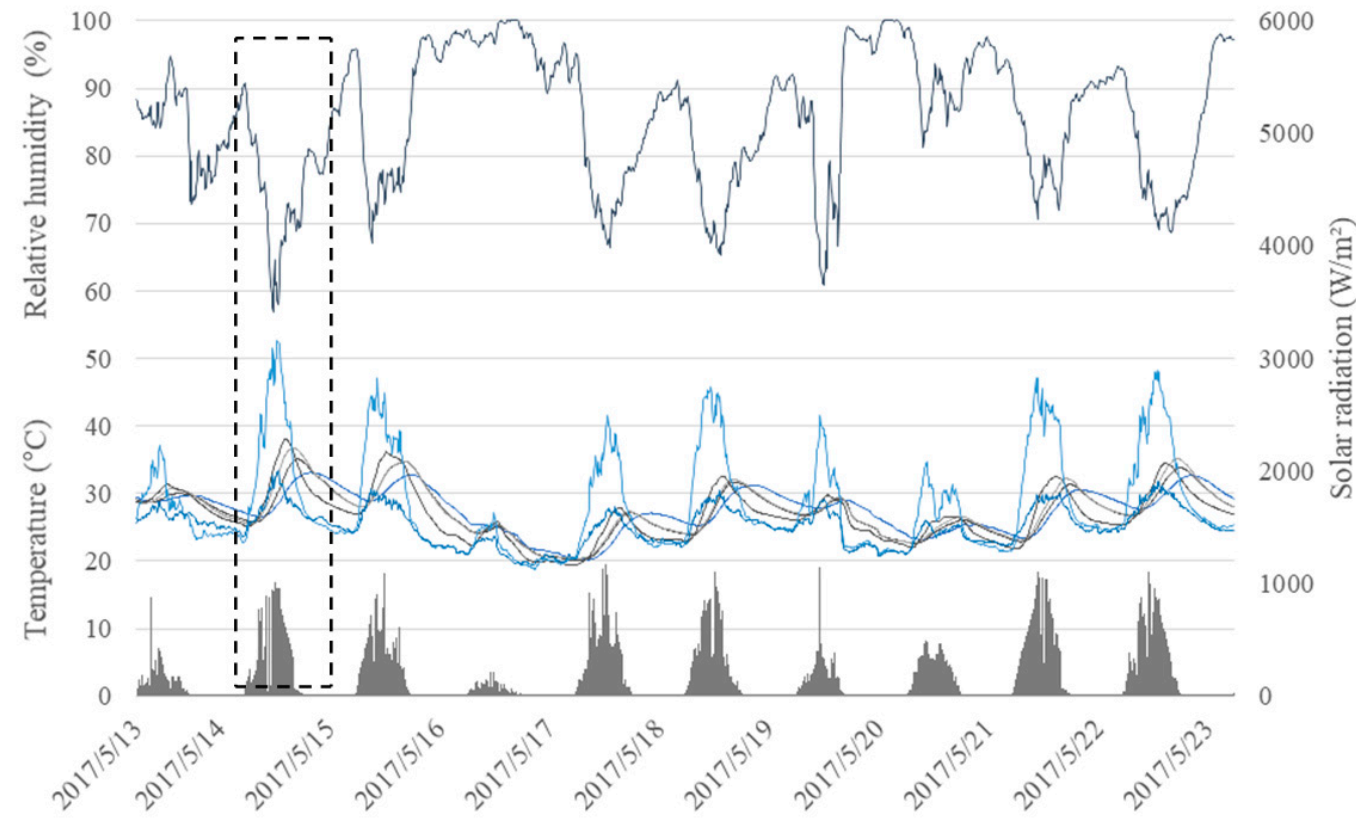

Figure 5. Temperatures, solar radiation, and relative humidity in the cases of 10, 15, 20, and $25 \mathrm{~cm}$ conventional garden-soil roofs without plants (13 May 2017 05:59:44 to 23 May 2017 05:49:44).

Because roofs with different depths of conventional garden soil resulted in the insulation, absorption, and evaporation effects, the thicker the growth medium, the greater the temperature reduction of the bare rooftop. On 14 May from 07:00 to 14:00, when the average air and rooftop temperatures were 29.18 and $41.72{ }^{\circ} \mathrm{C}$, respectively, the average temperatures at the bottom of the roofs with the conventional garden soil ( $0 \%$ LECA) at depths of 10, 15, 20, and $25 \mathrm{~cm}$ were 30.28, 28.91, 27.54, and $27.26^{\circ} \mathrm{C}$, respectively (Figures 6 and 7, Table 3). Consequently, the marginal temperature reduction achieved by the roofs with conventional garden-soil depths of $10,15,20$, and $25 \mathrm{~cm}$, determined as the ratio of the additional temperature reduction to the incremental increase in garden-soil depth (in other words, the additional temperature reduction of the bare rooftop as a result of a $1-\mathrm{cm}$ increase in garden soil depth), were $1.15^{\circ} \mathrm{C}$ for $10 \mathrm{~cm}, 0.27^{\circ} \mathrm{C}$ for $15 \mathrm{~cm}, 0.27^{\circ} \mathrm{C}$ for $20 \mathrm{~cm}$, and $0.06^{\circ} \mathrm{C}$ for $25 \mathrm{~cm}$ (Table 4). These results indicated a decline in the marginal temperature reduction with increasing garden-soil depth, suggesting that the roof with $10-\mathrm{cm}$ deep garden soil was the most efficient in reducing the temperature of the bare rooftop. We did not test the garden soil less than $10 \mathrm{~cm}$ because it is too shallow to grow healthy plants. Consequently, a $10 \mathrm{~cm}$ depth of growth medium was selected for the second, third and fourth stages. Noted that the reason for choosing the time frame of 07:00-14:00 to average the temperature reduction values was because this is the common and maximum lengthen of time frame for passive cooling effects to occur for four stages. 


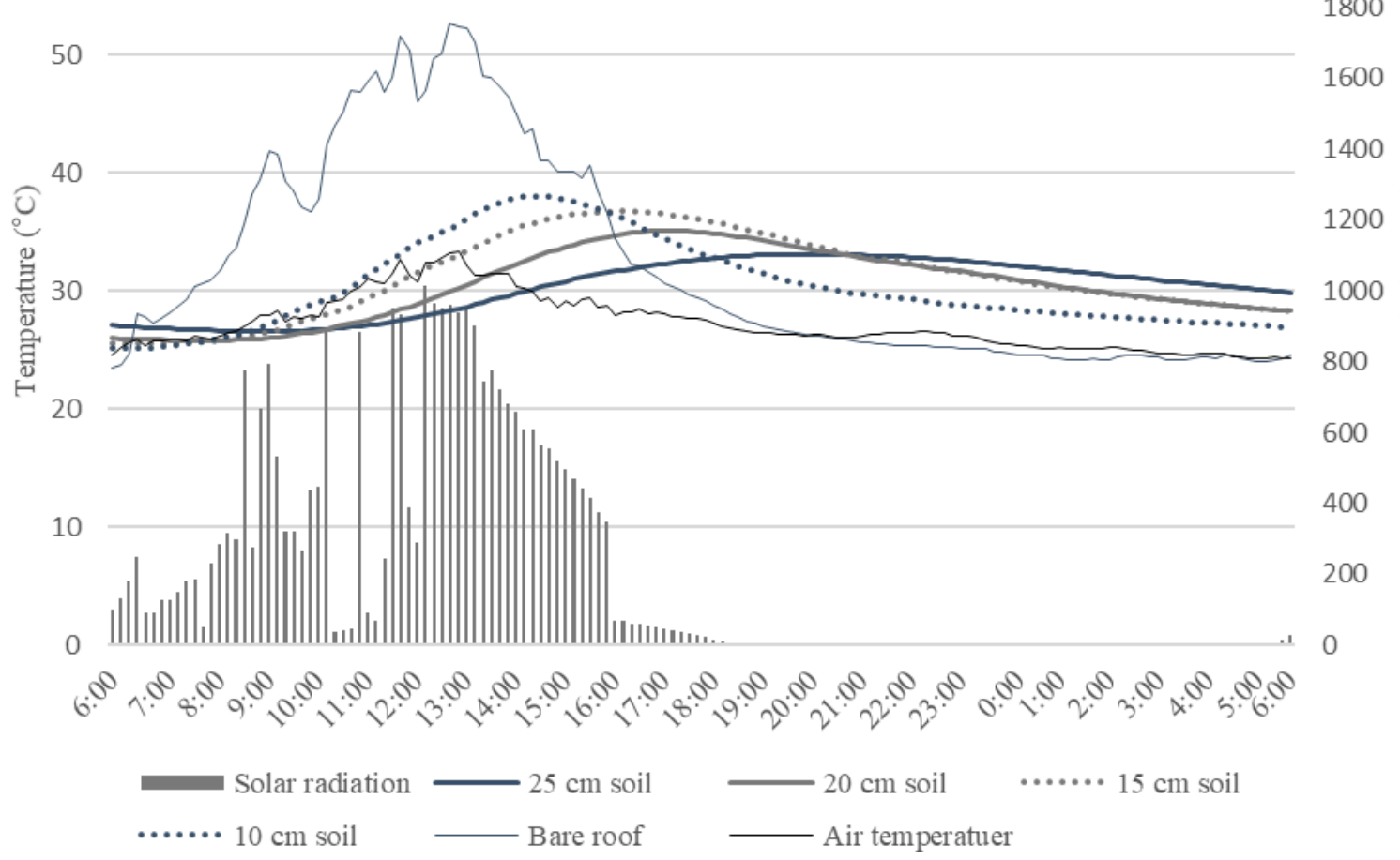

Figure 6. Temperatures and solar radiation in the cases of 10, 15, 20, and $25 \mathrm{~cm}$ conventional garden-soil roofs without plants (14 May 2017 05:59:44 to 15 May 05:49:44).

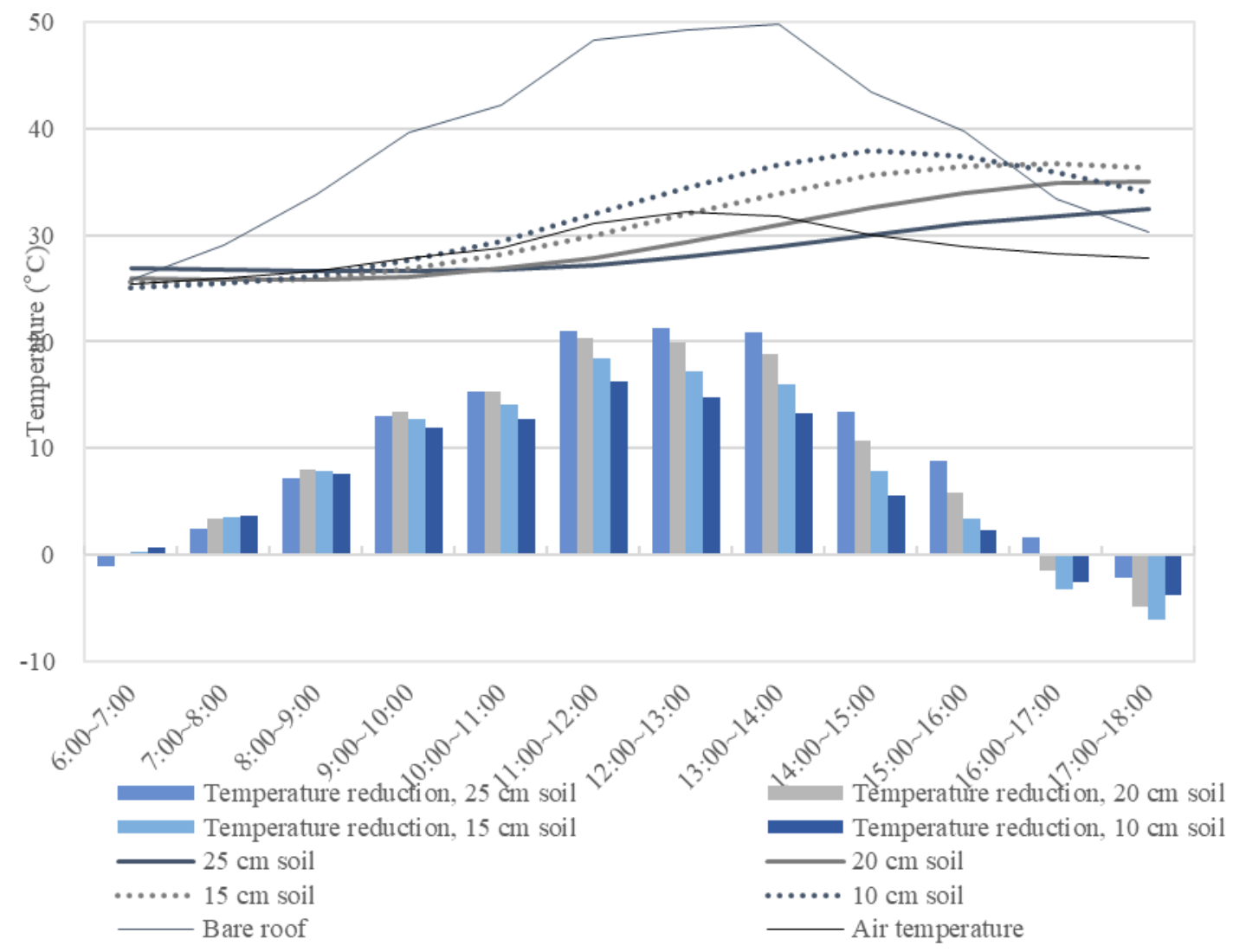

Figure 7. Temperatures and temperature reductions in the cases of 10, 15, 20, and $25 \mathrm{~cm}$ garden-soil roofs without plants (14 May 2017 05:59:44 to 14 May 2017 17:49:44). 
Table 3. Temperature at the bottom of the roofs and temperature reductions in the cases of 10, 15, 20, and 25 cm conventional garden-soil roofs without plants (14 May 2017 05:59:44 to 14 May 2017 17:49:44).

\begin{tabular}{|c|c|c|c|c|c|c|c|c|c|c|c|c|c|}
\hline \multicolumn{2}{|c|}{ Thermocouple Position } & $\begin{array}{c}\text { 06:00-07:00 } \\
\left({ }^{\circ} \mathrm{C}\right)\end{array}$ & $\begin{array}{c}\text { 07:00-08:00 } \\
\left({ }^{\circ} \mathrm{C}\right)\end{array}$ & $\begin{array}{c}\text { 08:00-09:00 } \\
\left({ }^{\circ} \mathrm{C}\right)\end{array}$ & $\begin{array}{c}\text { 09:00-10:00 } \\
\left({ }^{\circ} \mathrm{C}\right)\end{array}$ & $\begin{array}{c}\text { 10:00-11:00 } \\
\left({ }^{\circ} \mathrm{C}\right)\end{array}$ & $\begin{array}{c}\text { 11:00-12:00 } \\
\left({ }^{\circ} \mathrm{C}\right)\end{array}$ & $\begin{array}{c}\text { 12:00-13:00 } \\
\left({ }^{\circ} \mathrm{C}\right)\end{array}$ & $\begin{array}{c}\text { 13:00-14:00 } \\
\left({ }^{\circ} \mathrm{C}\right)\end{array}$ & $\begin{array}{c}\text { 14:00-15:00 } \\
\left({ }^{\circ} \mathrm{C}\right)\end{array}$ & $\begin{array}{c}\text { 15:00-16:00 } \\
\left({ }^{\circ} \mathrm{C}\right)\end{array}$ & $\begin{array}{c}\text { 16:00-17:00 } \\
\left({ }^{\circ} \mathrm{C}\right)\end{array}$ & $\begin{array}{c}\text { 17:00-18:00 } \\
\left({ }^{\circ} \mathrm{C}\right)\end{array}$ \\
\hline \multicolumn{2}{|r|}{ In the air } & 25.43 & 25.90 & 26.57 & 27.85 & 28.86 & 31.14 & 32.14 & 31.81 & 30.07 & 28.96 & 28.25 & 27.85 \\
\hline \multicolumn{2}{|c|}{ Bare rooftop surface } & 25.85 & 29.12 & 33.82 & 39.59 & 42.16 & 48.26 & 49.27 & 49.85 & 43.40 & 39.79 & 33.39 & 30.23 \\
\hline \multirow{4}{*}{$\begin{array}{l}\text { At the } \\
\text { bottom }\end{array}$} & $10 \mathrm{~cm}$ soil, no plants & 25.13 & 25.46 & 26.18 & 27.72 & 29.48 & 32.02 & 34.49 & 36.60 & 37.91 & 37.45 & 35.91 & 34.00 \\
\hline & $15 \mathrm{~cm}$ soil, no plants & 25.55 & 25.63 & 25.95 & 26.83 & 28.13 & 29.90 & 32.02 & 33.89 & 35.59 & 36.47 & 36.70 & 36.32 \\
\hline & $20 \mathrm{~cm}$ soil, no plants & 25.92 & 25.81 & 25.83 & 26.15 & 26.85 & 27.88 & 29.31 & 30.96 & 32.65 & 34.00 & 34.84 & 35.07 \\
\hline & $25 \mathrm{~cm}$ soil, no plants & 26.96 & 26.76 & 26.59 & 26.57 & 26.80 & 27.24 & 27.97 & 28.92 & 30.04 & 31.04 & 31.82 & 32.41 \\
\hline \multirow{4}{*}{$\begin{array}{l}\text { Temperature } \\
\text { Reduction }\end{array}$} & $10 \mathrm{~cm}$ soil, no plants & 0.73 & 3.66 & 7.64 & 11.87 & 12.68 & 16.24 & 14.79 & 13.25 & 5.49 & 2.35 & -2.52 & -3.77 \\
\hline & $15 \mathrm{~cm}$ soil, no plants & 0.30 & 3.49 & 7.87 & 12.76 & 14.03 & 18.36 & 17.26 & 15.97 & 7.81 & 3.33 & -3.31 & -6.09 \\
\hline & $20 \mathrm{~cm}$ soil, no plants & -0.07 & 3.32 & 7.99 & 13.44 & 15.32 & 20.38 & 19.97 & 18.90 & 10.75 & 5.79 & -1.45 & -4.83 \\
\hline & $25 \mathrm{~cm}$ soil, no plants & -1.11 & 2.37 & 7.23 & 13.02 & 15.36 & 21.02 & 21.30 & 20.93 & 13.36 & 8.75 & 1.57 & -2.18 \\
\hline
\end{tabular}

Table 4. Temperature reductions in the cases of 10, 15, 20, and $25 \mathrm{~cm}$ conventional garden-soil roofs without plants (14 May 2017 07:00-14:00).

\begin{tabular}{|c|c|c|c|c|c|c|}
\hline \multicolumn{2}{|c|}{ Thermocouple Position } & $\begin{array}{c}\text { Average } \\
\text { Temperature }\left({ }^{\circ} \mathrm{C}\right)\end{array}$ & $\begin{array}{c}\text { Average } \\
\text { Temperature } \\
\text { Reduction }\left({ }^{\circ} \mathrm{C}\right)\end{array}$ & $\begin{array}{l}\text { Additional Temperature } \\
\text { Reduction due to } \\
\text { Increased Soil Depth }\left({ }^{\circ} \mathrm{C}\right)\end{array}$ & $\begin{array}{l}\text { Incremental Increase } \\
\text { in Soil Depth }(\mathrm{cm})\end{array}$ & $\begin{array}{l}\text { Marginal Temperature } \\
\text { Reduction }\left({ }^{\circ} \mathrm{C}\right)\end{array}$ \\
\hline \multicolumn{2}{|c|}{ Air temperature } & 29.18 & - & - & - & - \\
\hline \multicolumn{2}{|c|}{ Bare rooftop surface } & 41.72 & - & - & - & - \\
\hline \multirow{4}{*}{ At the bottom } & $10 \mathrm{~cm}$ soil, no plants & 30.28 & 11.45 & 11.45 & 10 & 1.15 \\
\hline & $15 \mathrm{~cm}$ soil, no plants & 28.91 & 12.82 & 1.37 & 5 & 0.27 \\
\hline & $20 \mathrm{~cm}$ soil, no plants & 27.54 & 14.19 & 1.37 & 5 & 0.27 \\
\hline & $25 \mathrm{~cm}$ soil, no plants & 27.26 & 14.46 & 0.28 & 5 & 0.06 \\
\hline
\end{tabular}

Note: Marginal temperature reduction is determined as the ratio of additional temperature reduction to the incremental increase in conventional garden soil depth. 
3.2. Temperature Reduction When $0 \%, 10 \%, 40 \%$, and $70 \%$ LECA Were Laid at the Bottom and No Plants Were Used

The second stage (Figure 8) involved investigating the reductions in average temperature and heat amplitude owing to the extensive roof when different proportions of LECA were laid at the bottom of the tanks. The roofs with $0 \%, 10 \%, 40 \%$ and $70 \%$ LECA have $0,1,4,7 \mathrm{~cm}$ of LECA laid at the bottom of the tank, and 10, 9,6,3 cm of conventional garden soil laid at the top of the tanks, respectively. Table 5 shows that the mean air and rooftop temperatures were 29.15 and $33.96{ }^{\circ} \mathrm{C}$, respectively; the ranges of air and rooftop temperatures were $25.53-33.94{ }^{\circ} \mathrm{C}$ and $25.45-52.24{ }^{\circ} \mathrm{C}$, respectively; the maximum solar radiation was $1138.10 \mathrm{~W} / \mathrm{m}^{2}$; and the mean relative humidity was $80.88 \%$. A period of $24 \mathrm{~h}$ was selected for further analysis based on the aforementioned criteria. The date selected was 25-26 July 2017 (Figure 9).

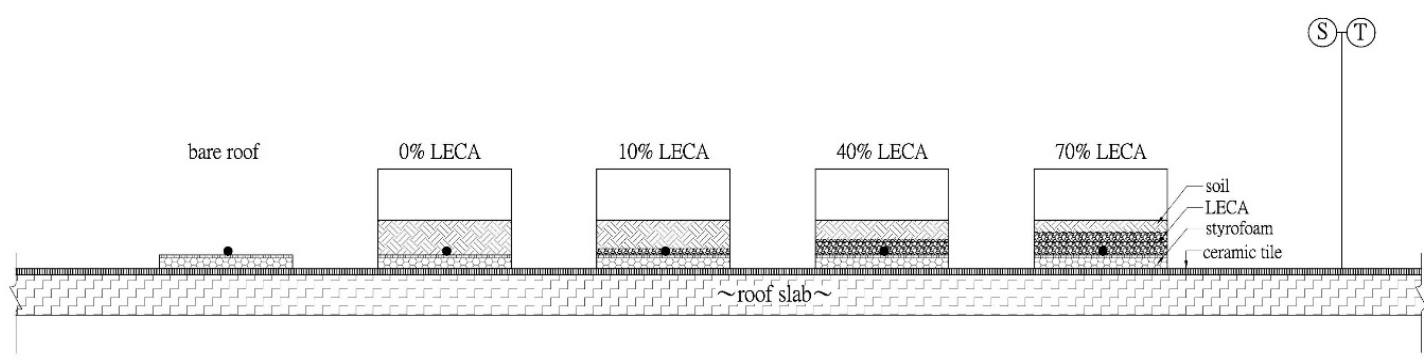

Figure 8. Experimental setup for the second stage.

Table 5. Weather data for the second stage (14 July 2017 06:00:09 to 26 July 2017).

\begin{tabular}{cc}
\hline Second Stage & Value \\
\hline Period of measurement & $14-26$ July 2017 \\
Range of air temperature & $25.53-33.94{ }^{\circ} \mathrm{C}$ \\
Mean air temperature & $29.15{ }^{\circ} \mathrm{C}$ \\
Range of rooftop temperature & $25.45-52.24{ }^{\circ} \mathrm{C}$ \\
Mean rooftop temperature & $33.96{ }^{\circ} \mathrm{C}$ \\
Maximum solar radiation & $1138.10 \mathrm{~W} / \mathrm{m}^{2}$ \\
Mean relative humidity & $80.88 \%$ \\
Date selected for further analysis (marked with dotted box) & $25-26 \mathrm{July} 2017$ \\
\hline
\end{tabular}

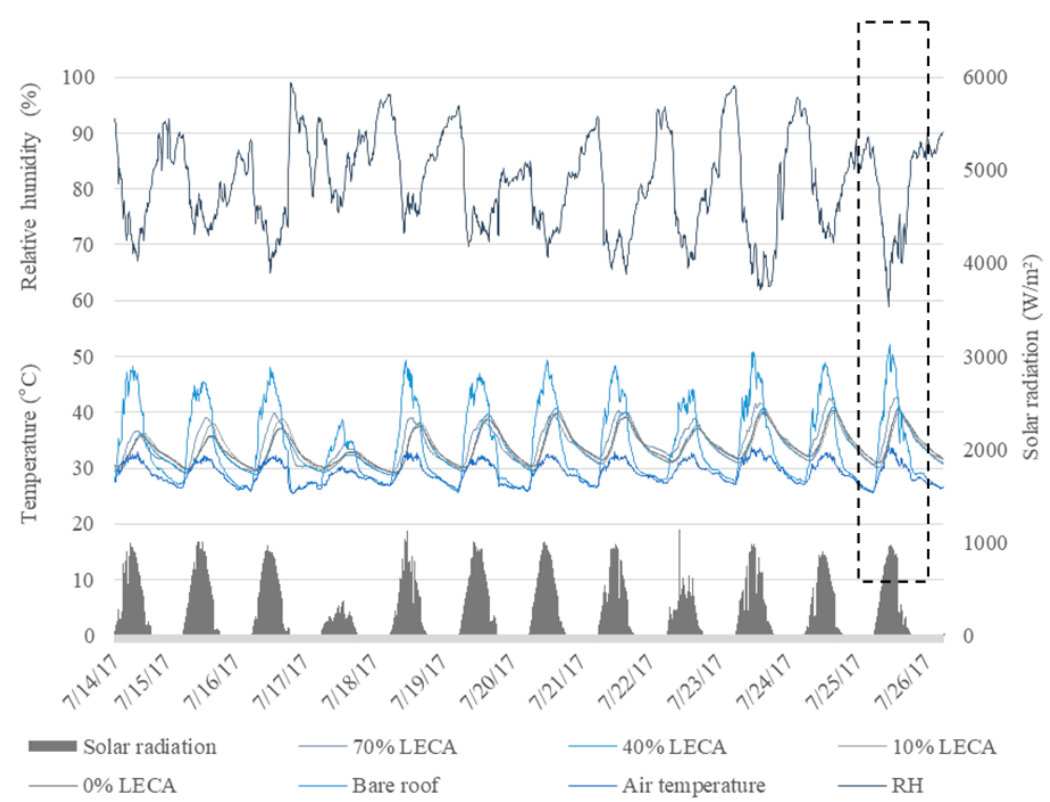

Figure 9. Temperatures, solar radiation, and relative humidity in the cases of $0 \%, 10 \%, 40 \%$, and $70 \%$ LECA laid at the bottom without plants (14 July 2017 06:00:09 to 26 July 2017 05:50:09). 
Roofs with various proportions of LECA exhibited different insulation, absorption, and evaporation effects in the garden-soil layer and additional insulation, absorption, and evaporation effects in the LECA layer. Consequently, the roofs with $10 \%$ and $40 \%$ LECA were not only lighter than the $0 \%$ LECA (conventional garden-soil) roof but also exhibited a lower average temperature in the bare rooftop than in the 0\% LECA roof. On 25 July from 07:00-14:00 (Table 6, Figure 10), when the average air temperature was $31.48^{\circ} \mathrm{C}$ and the average rooftop temperature was $44.28^{\circ} \mathrm{C}$, the average bottom temperatures of the roofs with $10 \%$ and $40 \%$ LECA were 33.71 and $34.34{ }^{\circ} \mathrm{C}$, respectively, whereas the average bottom temperature of the roof with $0 \%$ LECA was $34.74{ }^{\circ} \mathrm{C}$. These results indicated that roofs with $10 \%$ and $40 \%$ LECA reduced the average rooftop temperature by an additional 1.03 and $0.4{ }^{\circ} \mathrm{C}$, respectively. The roof with $70 \%$ LECA $\left(37.44^{\circ} \mathrm{C}\right)$ exhibited inferior temperature-reduction performance than the $0 \%$ LECA roof $\left(34.74{ }^{\circ} \mathrm{C}\right)$ by a difference of $2.70{ }^{\circ} \mathrm{C}$. Consequently, the proportions of $10 \%$ and $40 \%$ LECA were selected for the third and fourth stages.

Furthermore, all four extensive roofs containing different LECA proportions also contributed to stabilizing the rooftop temperature, which in turn mitigate the fluctuation of indoor temperature. Our experimental results revealed that the reduction of heat amplitude decreased as the proportion of LECA was increased. On July 25-26 (Table 7, Figure 11), the roof with $0 \%$ LECA and without plants reduced the heat amplitude of the bare rooftop by a significant $63.03 \%$, whereas the roofs with $10 \%$, $40 \%, 70 \%$ LECA and without plants reduced the heat amplitude of the bare rooftop by $61.91 \%, 58.47 \%$, and $53.40 \%$, respectively. The reduction in heat amplitude was calculated as 1 minus the ratio of fluctuation in the experimental temperature to fluctuation in the bare rooftop temperature. Compared with the roof with $70 \%$ LECA and without plants, the roof with $0 \%$ LECA and without plants provided an additional $9.63 \%$ reduction in the heat amplitude of the bare rooftop. In summary, although the roof with 10\% LECA and without plants yielded the largest reduction in the temperature of the bare rooftop, it is the roof with $0 \%$ LECA and without plants offered the largest reduction in heat amplitude of the bare rooftop.

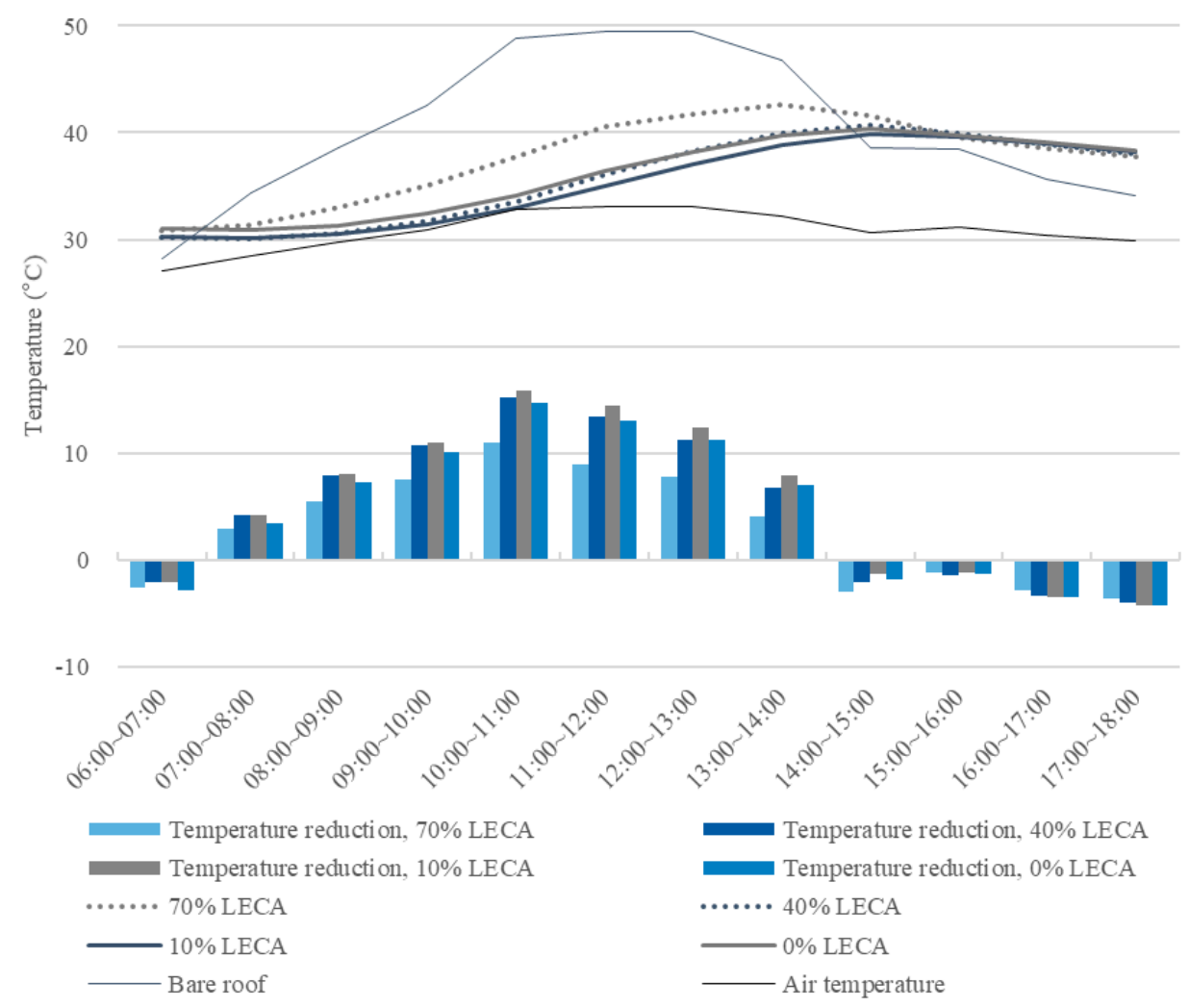

Figure 10. Temperatures and temperature reductions in the cases of the roofs with $0 \%, 10 \%, 40 \%$, and 70\% LECA laid at the bottom without plants (25 July 2017 06:00:09 to 25 July 2017 17:50:09). 
Table 6. Temperature at the bottom of the extensive roofs and temperature reductions in the cases of the extensive roofs with $0 \%, 10 \%, 40 \%$, and $70 \%$ LECA laid at the bottom without plants (25 July 2017 06:00:09 to 25 July 2017 17:50:09).

\begin{tabular}{|c|c|c|c|c|c|c|c|c|c|c|c|c|c|}
\hline \multicolumn{2}{|c|}{ Thermocouple Position } & $\begin{array}{c}\text { 06:00-07:00 } \\
\left({ }^{\circ} \mathrm{C}\right)\end{array}$ & $\begin{array}{c}\text { 07:00-08:00 } \\
\left({ }^{\circ} \mathrm{C}\right)\end{array}$ & $\begin{array}{c}\text { 08:00-09:00 } \\
\left({ }^{\circ} \mathrm{C}\right)\end{array}$ & $\begin{array}{c}\text { 09:00-10:00 } \\
\left({ }^{\circ} \mathrm{C}\right)\end{array}$ & $\begin{array}{c}\text { 10:00-11:00 } \\
\left({ }^{\circ} \mathrm{C}\right)\end{array}$ & $\begin{array}{c}\text { 11:00-12:00 } \\
\left({ }^{\circ} \mathrm{C}\right)\end{array}$ & $\begin{array}{c}\text { 12:00-13:00 } \\
\left({ }^{\circ} \mathrm{C}\right)\end{array}$ & $\begin{array}{c}\text { 13:00-14:00 } \\
\left({ }^{\circ} \mathrm{C}\right)\end{array}$ & $\begin{array}{c}\text { 14:00-15:00 } \\
\left({ }^{\circ} \mathrm{C}\right)\end{array}$ & $\begin{array}{c}\text { 15:00-16:00 } \\
\left({ }^{\circ} \mathrm{C}\right)\end{array}$ & $\begin{array}{c}\text { 16:00-17:00 } \\
\left({ }^{\circ} \mathrm{C}\right)\end{array}$ & $\begin{array}{c}17: 00-18: 00 \\
\left({ }^{\circ} \mathrm{C}\right)\end{array}$ \\
\hline \multicolumn{2}{|r|}{ In the air } & 27.04 & 28.49 & 29.73 & 30.93 & 32.87 & 33.15 & 33.06 & 32.16 & 30.70 & 31.20 & 30.37 & 29.90 \\
\hline \multicolumn{2}{|c|}{ Bare rooftop surface } & 28.20 & 34.32 & 38.59 & 42.53 & 48.78 & 49.47 & 49.51 & 46.73 & 38.59 & 38.41 & 35.64 & 34.09 \\
\hline \multirow{4}{*}{$\begin{array}{l}\text { At the } \\
\text { bottom }\end{array}$} & $0 \%$ LECA, no plants & 31.05 & 30.93 & 31.32 & 32.40 & 34.08 & 36.42 & 38.26 & 39.74 & 40.37 & 39.74 & 39.04 & 38.28 \\
\hline & 10\% LECA, no plants & 30.30 & 30.13 & 30.53 & 31.47 & 32.91 & 35.02 & 37.08 & 38.80 & 39.83 & 39.62 & 39.04 & 38.26 \\
\hline & 40\% LECA, no plants & 30.20 & 30.11 & 30.64 & 31.80 & 33.57 & 36.07 & 38.21 & 39.96 & 40.68 & 39.87 & 38.97 & 38.01 \\
\hline & $70 \%$ LECA, no plants & 30.80 & 31.35 & 33.06 & 35.01 & 37.77 & 40.54 & 41.74 & 42.60 & 41.60 & 39.55 & 38.51 & 37.72 \\
\hline \multirow{4}{*}{$\begin{array}{l}\text { Temperature } \\
\text { Reduction }\end{array}$} & $0 \%$ LECA, no plants & -2.85 & 3.39 & 7.27 & 10.13 & 14.70 & 13.05 & 11.25 & 6.98 & -1.78 & -1.33 & -3.40 & -4.19 \\
\hline & $10 \%$ LECA, no plants & -2.10 & 4.19 & 8.07 & 11.06 & 15.87 & 14.46 & 12.43 & 7.93 & -1.24 & -1.21 & -3.40 & -4.17 \\
\hline & $40 \%$ LECA, no plants & -2.00 & 4.21 & 7.96 & 10.73 & 15.21 & 13.40 & 11.30 & 6.77 & -2.09 & -1.46 & -3.33 & -3.92 \\
\hline & $70 \%$ LECA, no plants & -2.60 & 2.96 & 5.54 & 7.52 & 11.01 & 8.93 & 7.77 & 4.12 & -3.01 & -1.14 & -2.88 & -3.64 \\
\hline
\end{tabular}


Table 7. Reductions in heat amplitude in the cases of the roofs with $0 \%, 10 \%, 40 \%$, and 70\% LECA laid at the bottom without plants (25 July 2017 06:00:09 to 26 July 2017 05:50:09).

\begin{tabular}{|c|c|c|c|c|c|}
\hline \multicolumn{2}{|c|}{ Thermocouple Position } & $\begin{array}{c}\text { Average } \\
\text { Temperature } \\
\left({ }^{\circ} \mathrm{C}\right)\end{array}$ & $\begin{array}{c}\text { Range of } \\
\text { Temperature } \\
\left({ }^{\circ} \mathrm{C}\right)\end{array}$ & $\begin{array}{c}\text { Difference in } \\
\text { Temperature } \\
\left({ }^{\circ} \mathrm{C}\right)\end{array}$ & $\begin{array}{c}\text { Heat } \\
\text { Amplitude } \\
\text { Reduction }\end{array}$ \\
\hline \multicolumn{2}{|c|}{ In the air } & 29.13 & $26.33-33.94$ & 7.61 & - \\
\hline \multicolumn{2}{|c|}{ Bare rooftop surface } & 34.35 & $26.38-52.24$ & 25.86 & - \\
\hline \multirow{4}{*}{ At the bottom } & 0\% LECA, no plants & 35.13 & $30.90-40.46$ & 9.56 & $63.03 \%$ \\
\hline & $10 \%$ LECA, no plants & 34.46 & $30.09-39.94$ & 9.85 & $61.91 \%$ \\
\hline & $40 \%$ LECA, no plants & 34.55 & $30.04-40.78$ & 10.74 & $58.47 \%$ \\
\hline & 70\% LECA, no plants & 35.56 & $30.72-42.77$ & 12.05 & $53.40 \%$ \\
\hline
\end{tabular}

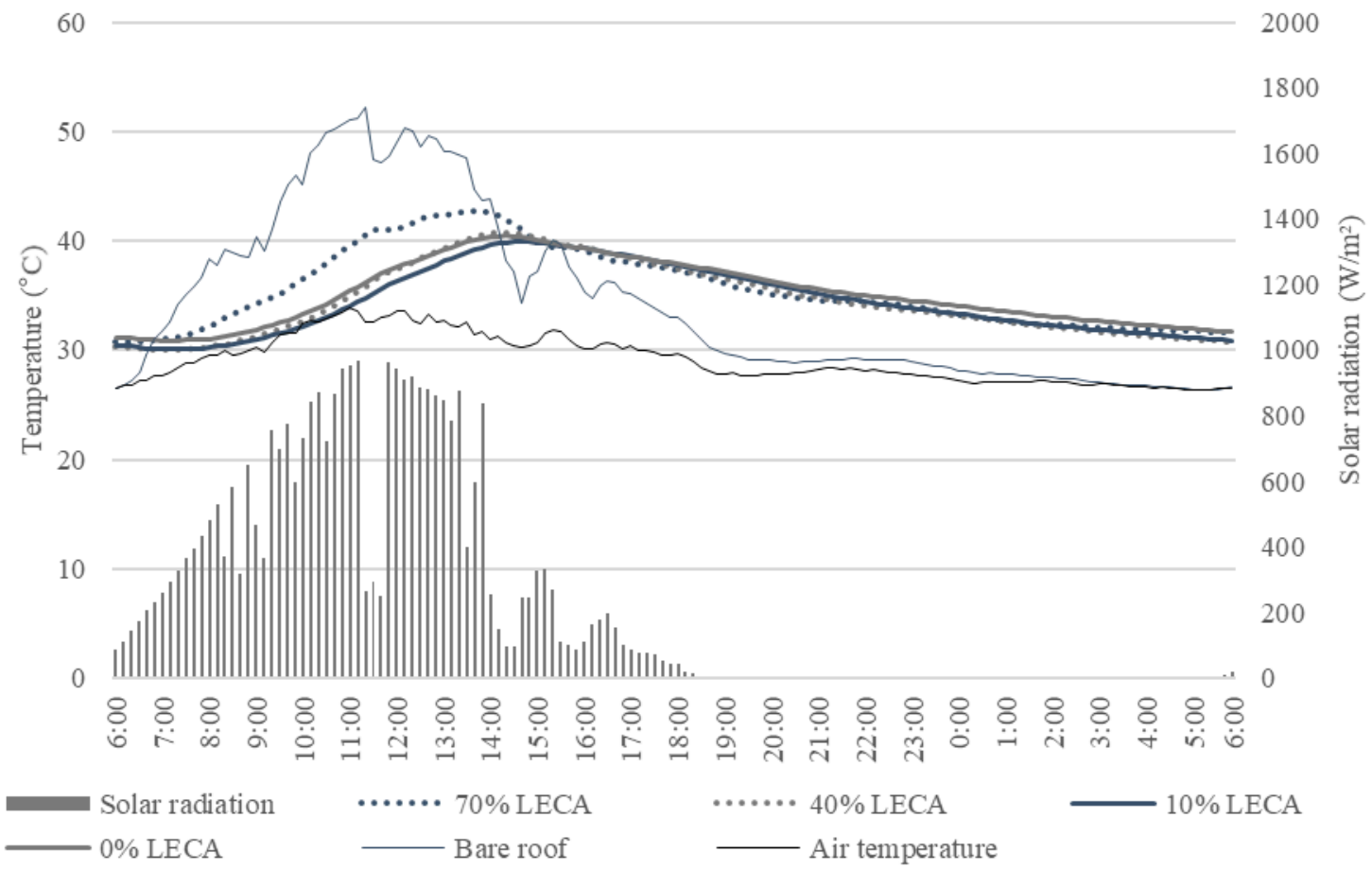

Figure 11. Temperatures and solar radiation in the cases of roofs with $0 \%, 10 \%, 40 \%$, and $70 \%$ LECA laid at the bottom without plants (25 July 2017 06:00:09 to 26 July 2017 05:50:09).

3.3. Temperature Reduction When 10\% and 40\% LECA Were Laid at the Bottom without Plants and When $10 \%$ and $40 \%$ LECA Were Mixed with the Soil without Plants

The third stage (Figure 12) involved investigating the reductions in temperature and heat amplitude of the bare rooftop owing to the extensive roofs with $10 \%$ and $40 \%$ LECA laid at the bottom or mixed with the conventional garden soil without plants. Table 8 shows that the mean air and rooftop temperatures were 29.29 and $35.42{ }^{\circ} \mathrm{C}$, respectively; the ranges of air and rooftop temperatures were $25.74-34.76^{\circ} \mathrm{C}$ and $23.55-61.49^{\circ} \mathrm{C}$, respectively; the maximum solar radiation was $873.10 \mathrm{~W} / \mathrm{m}^{2}$; and the mean relative humidity was $80.93 \%$. A period of $24 \mathrm{~h}$ was selected for further analysis based on the aforementioned criteria. The date selected was 24-25 September 2017 (Figure 13).

Because roofs with various proportions and placements of LECA without plants resulted in the insulation, absorption, and evaporation effects of the soil layer and the LECA layer, the roofs with $10 \%$ LECA and without plants exhibited a greater temperature reduction on the bare rooftop than did the roofs with 40\% LECA and without plants. On 24 September from 07:00-14:00 (Table 9, Figure 14), when the average air and rooftop temperatures were $32.08{ }^{\circ} \mathrm{C}$ and $50.14{ }^{\circ} \mathrm{C}$, respectively, the average bottom temperatures of the roofs with $10 \%$ and $40 \%$ LECA laid at the bottom and without plants were 36.32 and $37.26^{\circ} \mathrm{C}$, respectively; the average bottom temperatures of the roofs with $10 \%$ and $40 \%$ LECA 
mixed with the soil and without plants were 36.22 and $38.63{ }^{\circ} \mathrm{C}$, respectively. These results indicated that the roofs with $10 \%$ LECA laid at the bottom and mixed with the soil (both without plants) can reduce the average bare rooftop temperature by an additional 0.94 and $2.41{ }^{\circ} \mathrm{C}$, respectively, than their counterparts with 40\% LECA laid at the bottom and mixed with the soil (both without plants). If brief, the extensive roofs with 10\% LECA and without plants demonstrated superior passive cooling performance compared with the extensive roofs with $40 \%$ LECA and without plants.

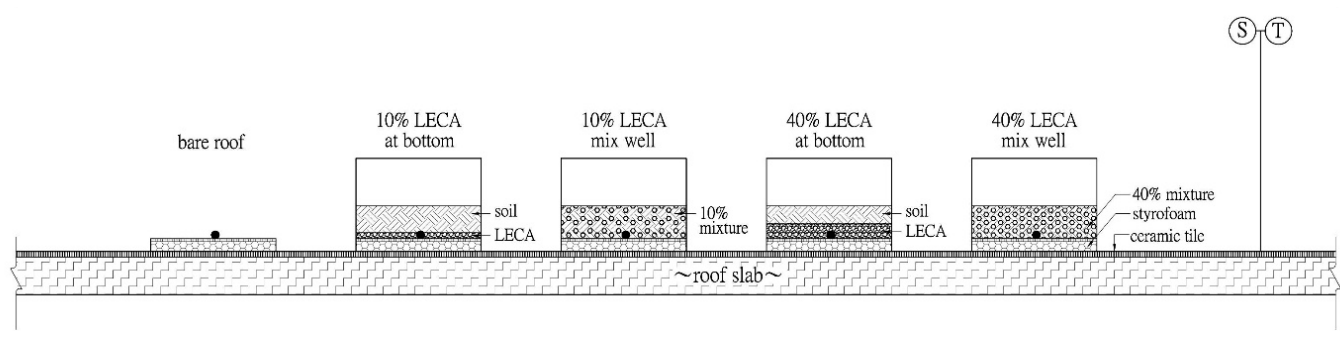

Figure 12. Experimental setup for the third stage.

Table 8. Weather data for the third stage (2017/09/20 06:08:41 to 2017/09/27 05:58:41).

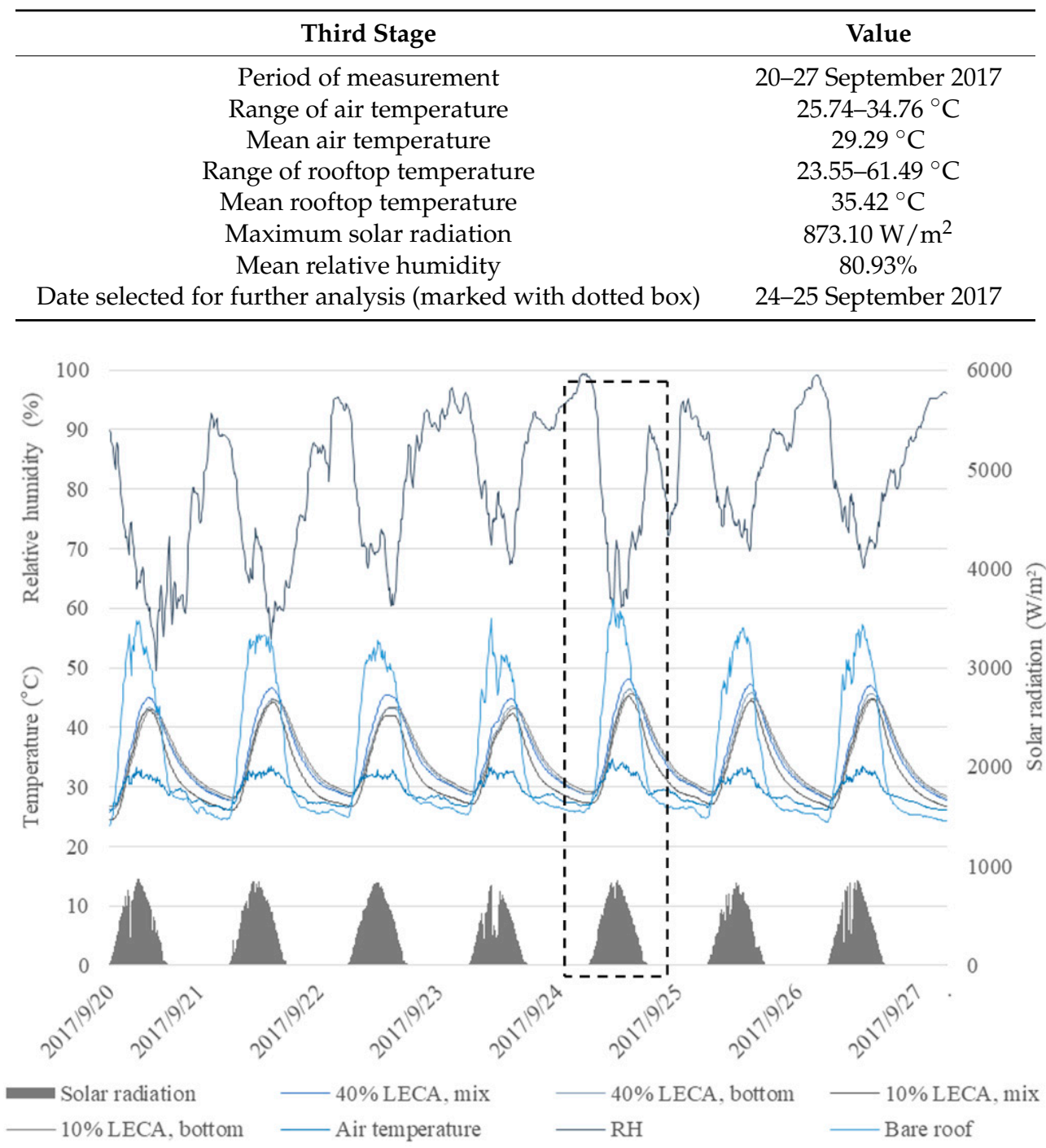

Figure 13. Temperatures, solar radiation, and relative humidity in the cases of roofs with $10 \%$ and $40 \%$ LECA laid at the bottom without plants, and of $10 \%$ and $40 \%$ LECA mixed with the soil without plants (20 September 2017 06:08:41 to 27 September 2017 05:58:41). 
Table 9. Temperatures at the bottom of the roofs and temperature reductions in the cases of roofs with $10 \%$ and $40 \%$ LECA laid at the bottom without plants, and of 10\% and 40\% LECA mixed with the soil without plants (24 September 2017 06:08:41 to 24 September 2017 17:58:41).

\begin{tabular}{|c|c|c|c|c|c|c|c|c|c|c|c|c|c|}
\hline \multicolumn{2}{|r|}{ Thermocouple Position } & $\begin{array}{c}06: 00-07: 00 \\
\left({ }^{\circ} \mathrm{C}\right)\end{array}$ & $\begin{array}{c}\text { 07:00-08:00 } \\
\left({ }^{\circ} \mathrm{C}\right)\end{array}$ & $\begin{array}{c}\text { 08:00-09:00 } \\
\left({ }^{\circ} \mathrm{C}\right)\end{array}$ & $\begin{array}{c}\text { 09:00-10:00 } \\
\left({ }^{\circ} \mathrm{C}\right)\end{array}$ & $\begin{array}{c}\text { 10:00-11:00 } \\
\left({ }^{\circ} \mathrm{C}\right)\end{array}$ & $\begin{array}{c}\text { 11:00-12:00 } \\
\left({ }^{\circ} \mathrm{C}\right)\end{array}$ & $\begin{array}{c}\text { 12:00-13:00 } \\
\left({ }^{\circ} \mathrm{C}\right)\end{array}$ & $\begin{array}{c}\text { 13:00-14:00 } \\
\left({ }^{\circ} \mathrm{C}\right)\end{array}$ & $\begin{array}{c}\text { 14:00-15:00 } \\
\left({ }^{\circ} \mathrm{C}\right)\end{array}$ & $\begin{array}{c}\text { 15:00-16:00 } \\
\left({ }^{\circ} \mathrm{C}\right)\end{array}$ & $\begin{array}{c}\text { 16:00-17:00 } \\
\left({ }^{\circ} \mathrm{C}\right)\end{array}$ & $\begin{array}{c}17: 00-18: 00 \\
\left({ }^{\circ} \mathrm{C}\right)\end{array}$ \\
\hline \multicolumn{2}{|r|}{ In the air } & 27.19 & 28.44 & 30.40 & 31.80 & 33.76 & 33.23 & 33.60 & 33.35 & 32.42 & 32.19 & 31.21 & 29.67 \\
\hline \multicolumn{2}{|r|}{ Bare rooftop surface } & 26.90 & 30.75 & 40.10 & 48.77 & 58.08 & 59.11 & 58.38 & 55.77 & 50.42 & 45.67 & 39.95 & 32.81 \\
\hline \multirow{4}{*}{$\begin{array}{l}\text { At the } \\
\text { bottom }\end{array}$} & $10 \%$ LECA, bottom, no plants & 29.13 & 29.32 & 30.40 & 32.59 & 35.90 & 39.38 & 42.26 & 44.42 & 45.51 & 45.29 & 44.39 & 42.55 \\
\hline & $10 \%$ LECA, mix, no plants & 27.26 & 27.62 & 29.14 & 32.11 & 36.24 & 40.46 & 43.19 & 44.80 & 45.00 & 43.79 & 41.50 & 38.36 \\
\hline & $40 \%$ LECA, bottom, no plants & 28.74 & 29.12 & 30.60 & 33.28 & 37.26 & 41.06 & 43.78 & 45.74 & 46.24 & 45.27 & 43.93 & 41.80 \\
\hline & 40\% LECA, mix, no plants & 28.78 & 29.34 & 31.19 & 34.31 & 38.88 & 42.99 & 45.96 & 47.72 & 47.84 & 46.23 & 44.21 & 41.36 \\
\hline \multirow{4}{*}{$\begin{array}{l}\text { Temperature } \\
\text { reduction }\end{array}$} & $10 \%$ LECA, bottom, no plants & -2.22 & 1.44 & 9.70 & 16.18 & 22.18 & 19.74 & 16.12 & 11.36 & 4.91 & 0.38 & -4.44 & -9.75 \\
\hline & $10 \%$ LECA, mix, no plants & -0.36 & 3.14 & 10.96 & 16.66 & 21.84 & 18.65 & 15.19 & 10.97 & 5.42 & 1.88 & -1.55 & -5.55 \\
\hline & $40 \%$ LECA, bottom, no plants & -1.83 & 1.64 & 9.50 & 15.49 & 20.83 & 18.06 & 14.60 & 10.04 & 4.18 & 0.40 & -3.98 & -9.00 \\
\hline & $40 \%$ LECA, mix, no plants & -1.88 & 1.41 & 8.91 & 14.47 & 19.21 & 16.12 & 12.42 & 8.06 & 2.58 & -0.56 & -4.26 & -8.55 \\
\hline
\end{tabular}




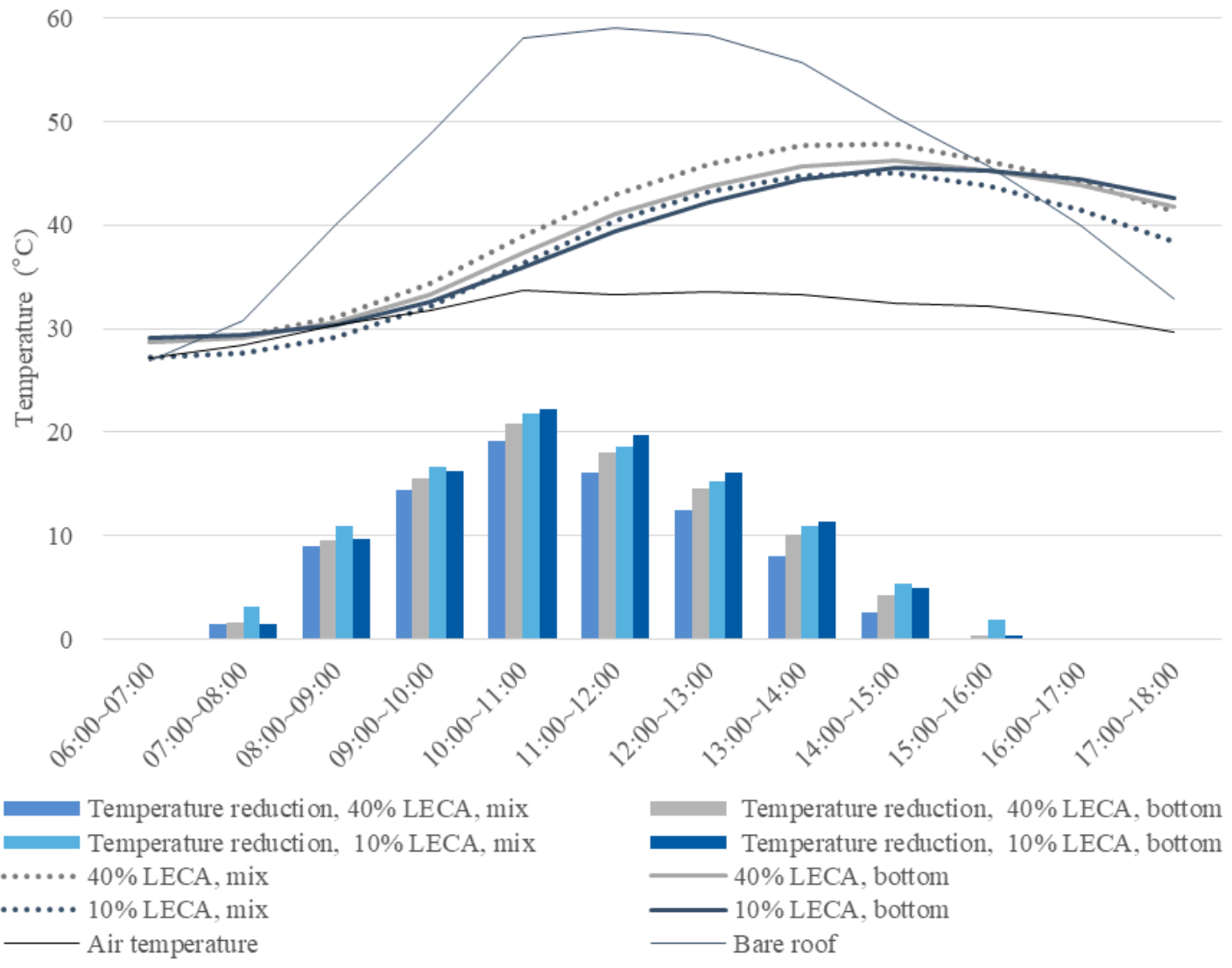

Figure 14. Temperatures and temperature reductions in the cases of the roofs with $10 \%$ and $40 \%$ LECA laid at the bottom without plants, and of $10 \%$ and $40 \%$ LECA mixed with the soil without plants (24 September 2017 06:08:41 to 24 September 2017 17:58:41).

All four extensive roofs containing different proportions and placements of LECA contributed to stabilizing the temperature of bare rooftop, which in turn mitigate the fluctuation of indoor temperatures and hence increased comfort level in the rooms underneath the roofs. Our experimental results revealed that the roofs with $10 \%$ LECA and without plants yielded a larger reduction in the heat amplitude of the bare rooftop than did the roof with 40\% LECA and without plants. On 24-25 September (Table 10, Figure 15) when the average air and rooftop temperatures were 29.86 and $36.11^{\circ} \mathrm{C}$, respectively, the roof with $10 \%$ LECA laid at the bottom and without plants (54.98\%) reduced the heat amplitude of the bare rooftop by a further $3.10 \%$ more than the roof with $40 \%$ LECA laid at the bottom without plants (51.88\%); the roof with 10\% LECA mixed with the soil and without plants $(50.98 \%)$ further reduced the heat amplitude of the bare rooftop by $3.68 \%$ more than the roof with $40 \%$ LECA mixed with the soil without plants $(47.30 \%)$.

Table 10. Reduction in the heat amplitude in the cases of the roofs with $10 \%$ and $40 \%$ LECA laid at the bottom without plants, and of $10 \%$ and $40 \%$ LECA mixed with the soil without plants (24 September 2017 06:08:41 to 25 September 2017 05:58:41).

\begin{tabular}{|c|c|c|c|c|c|}
\hline \multicolumn{2}{|c|}{ Thermocouple Position } & $\begin{array}{c}\text { Average } \\
\text { Temperature } \\
\left({ }^{\circ} \mathrm{C}\right)\end{array}$ & $\begin{array}{c}\text { Range of } \\
\text { Temperature } \\
\left({ }^{\circ} \mathrm{C}\right)\end{array}$ & $\begin{array}{c}\text { Difference } \\
\text { inTemperature } \\
\left({ }^{\circ} \mathrm{C}\right)\end{array}$ & $\begin{array}{c}\text { Heat } \\
\text { Amplitude } \\
\text { Reduction }\end{array}$ \\
\hline & In the air & 29.86 & $26.50-34.76$ & 8.26 & - \\
\hline & rooftop surface & 36.11 & $24.77-61.49$ & 36.72 & - \\
\hline \multirow{4}{*}{ At the bottom } & $10 \%$ LECA, bottom, no plants & 35.79 & $29.09-45.62$ & 16.53 & $54.98 \%$ \\
\hline & 10\% LECA, mix, no plants & 33.89 & $27.19-45.19$ & 18.00 & $50.98 \%$ \\
\hline & $40 \%$ LECA, bottom, no plants & 35.96 & 28.72-46.39 & 17.67 & $51.88 \%$ \\
\hline & 40\% LECA, mix, no plants & 36.23 & $28.72-48.07$ & 19.35 & $47.30 \%$ \\
\hline
\end{tabular}




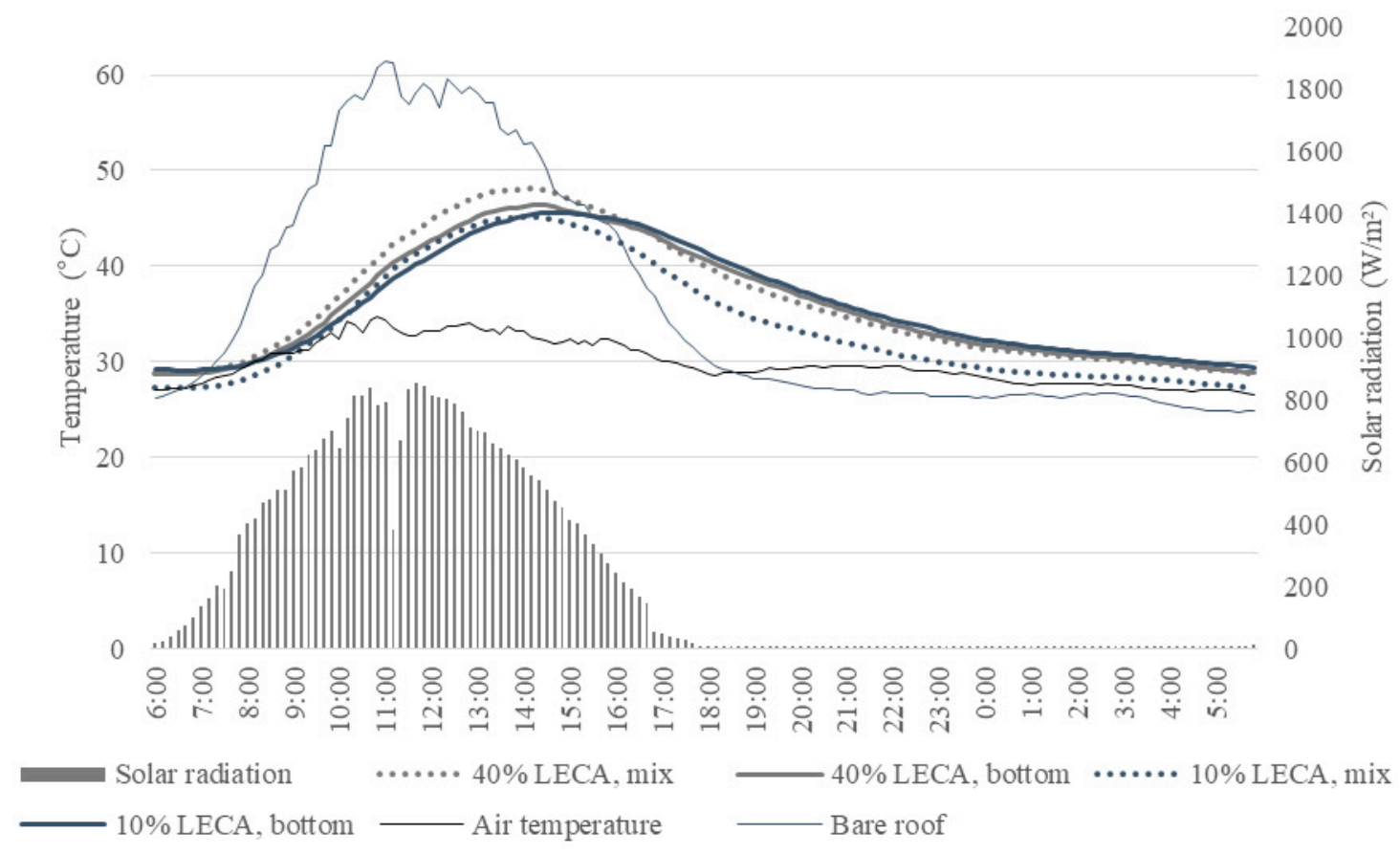

Figure 15. Temperatures and solar radiation in the cases of roofs with $10 \%$ and $40 \%$ LECA laid at the bottom without plants, and of 10\% and 40\% LECA mixed with the soil without plants (24 September 2017 06:08:41 to 25 September 2017 05:58:41).

3.4. Temperature Reduction When 10\% and 40\% LECA Were Laid at the Bottom with Plants and When 10\% and $40 \%$ LECA Were Mixed with the Soil with Plants

The fourth stage (Figure 16) involved investigating the reductions in temperature and heat amplitude of the bare rooftop owing to the extensive roofs with 10\% and 40\% LECA laid at the bottom or mixed with the soil and with plants. Table 11 shows that the mean air and rooftop temperatures were 28.80 and $33.80{ }^{\circ} \mathrm{C}$, respectively; the ranges of air temperature and rooftop temperature were $24.12-35.72{ }^{\circ} \mathrm{C}$ and $23.04-61.90^{\circ} \mathrm{C}$, respectively; the maximum solar radiation was $921.90 \mathrm{~W} / \mathrm{m}^{2}$; and the mean relative humidity was $82.15 \%$. A period of $24 \mathrm{~h}$ was selected for further analysis based on the aforementioned criteria. The date selected was 1-2 October 2017 (Figure 17).

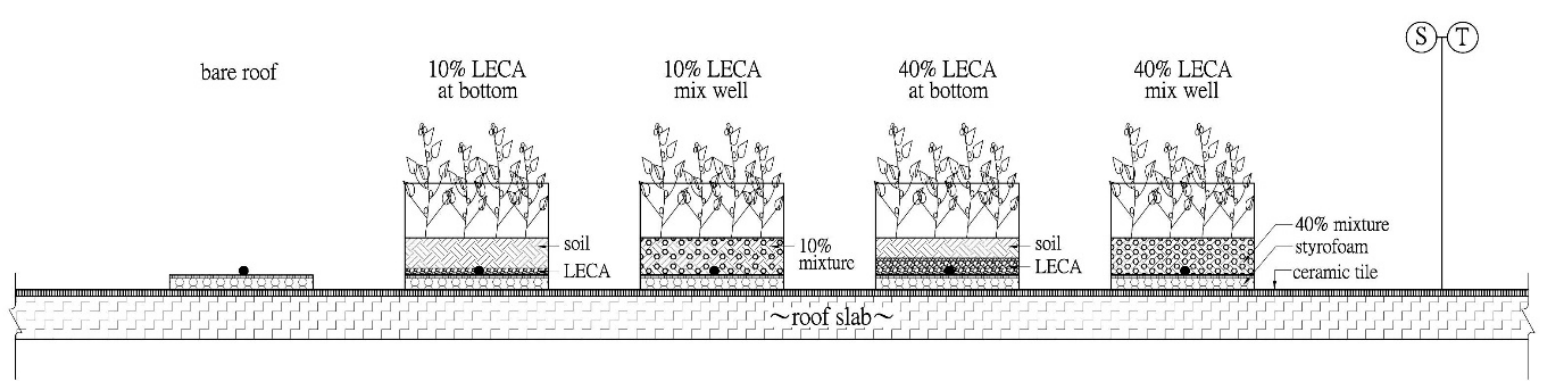

Figure 16. Experimental setup for the fourth stage. 
Table 11. Weather data for the fourth stage (28 September 2017 06:07:57 to 13 October 2017 05:57:57).

\begin{tabular}{cc}
\hline Fourth Stage & Value \\
\hline Period of measurement & 28 September $2017-13$ October 2017 \\
Range of air temperature & $24.12-35.72{ }^{\circ} \mathrm{C}$ \\
Mean air temperature & $28.80{ }^{\circ} \mathrm{C}$ \\
Range of rooftop temperature & $23.04-61.90^{\circ} \mathrm{C}$ \\
Mean rooftop temperature & $33.80{ }^{\circ} \mathrm{C}$ \\
Maximum solar radiation & $921.90 \mathrm{~W} / \mathrm{m}^{2}$ \\
Mean relative humidity & $82.15 \%$ \\
Date selected for further analysis (marked with dotted box) & $1-2$ October 2017 \\
\hline
\end{tabular}

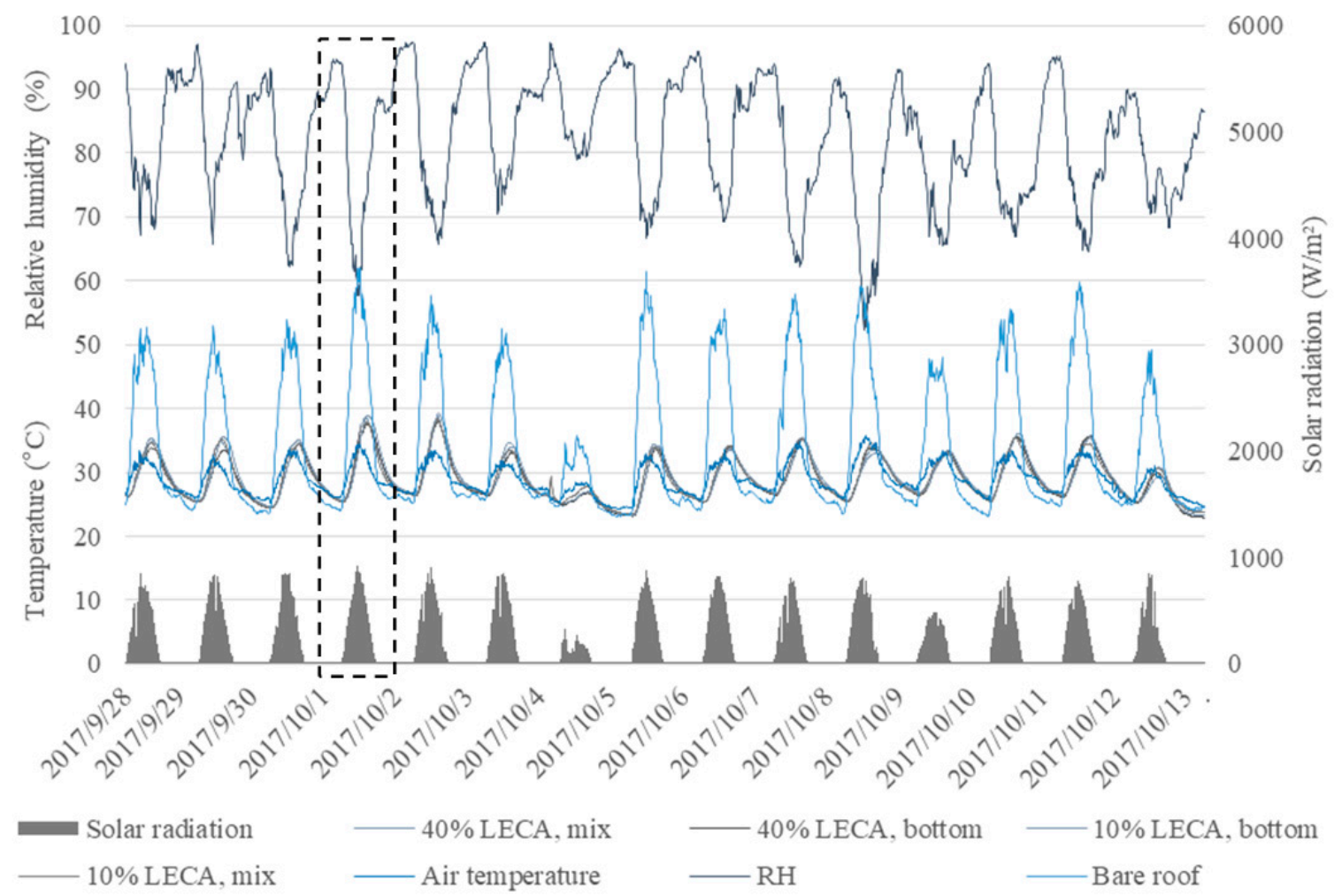

Figure 17. Temperatures, solar radiation, and relative humidity in the cases of roofs with $10 \%$ and $40 \%$ LECA laid at the bottom with Ipomoea batatas, and of 10\% and 40\% LECA mixed with soil with Ipomoea batatas (28 September 2017 06:07:57 to 13 October 2017 05:57:57).

Because roofs with various proportions and placements of LECA with plants resulted in the insulation, absorption, and evaporation effects of the soil and LECA layers as well as demonstrated additional reflective, photosynthetic, shielding, shading, and evapotranspiration effects on the Ipomoea batata layer, the roofs with 10\% LECA with plants yielded a greater reduction in the bare rooftop surface temperature than roofs with 40\% LECA with plants. On October 1 from 07:00-14:00 (Table 12, Figure 18), when the average air and rooftop temperatures were $32.04{ }^{\circ} \mathrm{C}$ and $50.53{ }^{\circ} \mathrm{C}$, respectively, the average bottom temperatures of the roofs with $10 \%$ and $40 \%$ LECA laid at the bottom and with plants were 30.80 and $31.17^{\circ} \mathrm{C}$, respectively; the average bottom temperatures of the roofs with $10 \%$ and $40 \%$ LECA mixed with the soil and with plants were 31.80 and $32.09^{\circ} \mathrm{C}$, respectively. These results indicated that roofs with 10\% LECA laid at the bottom and mixed with the soil (both with plants) can reduced the average rooftop temperature by an additional 0.36 and $0.29^{\circ} \mathrm{C}$ more than their counterparts with $40 \%$ LECA laid at the bottom and mixed with the soil (both with plants), respectively. In brief, the extensive roof with 10\% LECA and with plants demonstrated a slightly greater passive-cooling performance compared with the extensive roofs with $40 \%$ LECA and with plants. 
Table 12. Temperatures at the bottom of the roofs and temperature reductions in the cases of the roofs with $10 \%$ and $40 \%$ LECA laid at the bottom with Ipomoea batatas, and of 10\% and 40\% LECA mixed with the soil with Ipomoea batatas (1 October 2017 06:07:57 to 1 October 2017 17:57:57).

\begin{tabular}{|c|c|c|c|c|c|c|c|c|c|c|c|c|c|}
\hline & Thermocouple Position & $\begin{array}{c}\text { 06:00-07:00 } \\
\left({ }^{\circ} \mathrm{C}\right)\end{array}$ & $\begin{array}{c}\text { 07:00-08:00 } \\
\left({ }^{\circ} \mathrm{C}\right)\end{array}$ & $\begin{array}{c}\text { 08:00-09:00 } \\
\left({ }^{\circ} \mathrm{C}\right)\end{array}$ & $\begin{array}{c}\text { 09:00-10:00 } \\
\left({ }^{\circ} \mathrm{C}\right)\end{array}$ & $\begin{array}{c}\text { 10:00-11:00 } \\
\left({ }^{\circ} \mathrm{C}\right)\end{array}$ & $\begin{array}{c}\text { 11:00-12:00 } \\
\left({ }^{\circ} \mathrm{C}\right)\end{array}$ & $\begin{array}{c}\text { 12:00-13:00 } \\
\left({ }^{\circ} \mathrm{C}\right)\end{array}$ & $\begin{array}{c}\text { 13:00-14:00 } \\
\left({ }^{\circ} \mathrm{C}\right)\end{array}$ & $\begin{array}{c}\text { 14:00-15:00 } \\
\left({ }^{\circ} \mathrm{C}\right)\end{array}$ & $\begin{array}{c}\text { 15:00-16:00 } \\
\left({ }^{\circ} \mathrm{C}\right)\end{array}$ & $\begin{array}{c}\text { 16:00-17:00 } \\
\left({ }^{\circ} \mathrm{C}\right)\end{array}$ & $\begin{array}{c}17: 00-18: 00 \\
\left({ }^{\circ} \mathrm{C}\right)\end{array}$ \\
\hline & In the air & 26.86 & 28.18 & 30.21 & 31.65 & 33.00 & 34.12 & 34.03 & 33.08 & 32.32 & 31.07 & 29.74 & 28.70 \\
\hline & Bare rooftop surface & 25.43 & 31.57 & 41.23 & 49.19 & 56.61 & 60.32 & 58.98 & 55.83 & 50.96 & 44.17 & 38.07 & 31.28 \\
\hline \multirow{4}{*}{$\begin{array}{l}\text { At the } \\
\text { bottom }\end{array}$} & $10 \%$ LECA, bottom, with plants & 25.50 & 25.68 & 26.53 & 28.04 & 30.14 & 32.60 & 35.28 & 37.33 & 38.69 & 38.72 & 37.91 & 36.40 \\
\hline & $10 \%$ LECA, mix, with plants & 25.37 & 25.80 & 27.24 & 29.25 & 31.70 & 34.46 & 36.68 & 37.49 & 37.84 & 37.25 & 35.61 & 33.61 \\
\hline & $40 \%$ LECA, bottom, with plants & 25.31 & 25.74 & 26.99 & 28.73 & 31.13 & 33.45 & 35.51 & 36.62 & 37.55 & 37.31 & 36.44 & 34.97 \\
\hline & $40 \%$ LECA, mix, with plants & 25.57 & 25.98 & 27.17 & 29.28 & 32.19 & 34.69 & 37.09 & 38.24 & 38.46 & 37.35 & 36.02 & 34.46 \\
\hline \multirow{4}{*}{$\begin{array}{l}\text { Temperature } \\
\text { reduction }\end{array}$} & $10 \%$ LECA, bottom, with plants & -0.07 & 5.90 & 14.70 & 21.15 & 26.47 & 27.73 & 23.70 & 18.50 & 12.27 & 5.45 & 0.16 & -5.13 \\
\hline & $10 \%$ LECA, mix, with plants & 0.06 & 5.77 & 13.99 & 19.95 & 24.90 & 25.87 & 22.31 & 18.35 & 13.12 & 6.93 & 2.46 & -2.33 \\
\hline & $40 \%$ LECA, bottom, with plants & 0.12 & 5.84 & 14.24 & 20.46 & 25.47 & 26.87 & 23.47 & 19.22 & 13.41 & 6.86 & 1.64 & -3.69 \\
\hline & 40\% LECA, mix, with plants & -0.14 & 5.59 & 14.06 & 19.91 & 24.42 & 25.64 & 21.89 & 17.60 & 12.50 & 6.82 & 2.06 & -3.18 \\
\hline
\end{tabular}




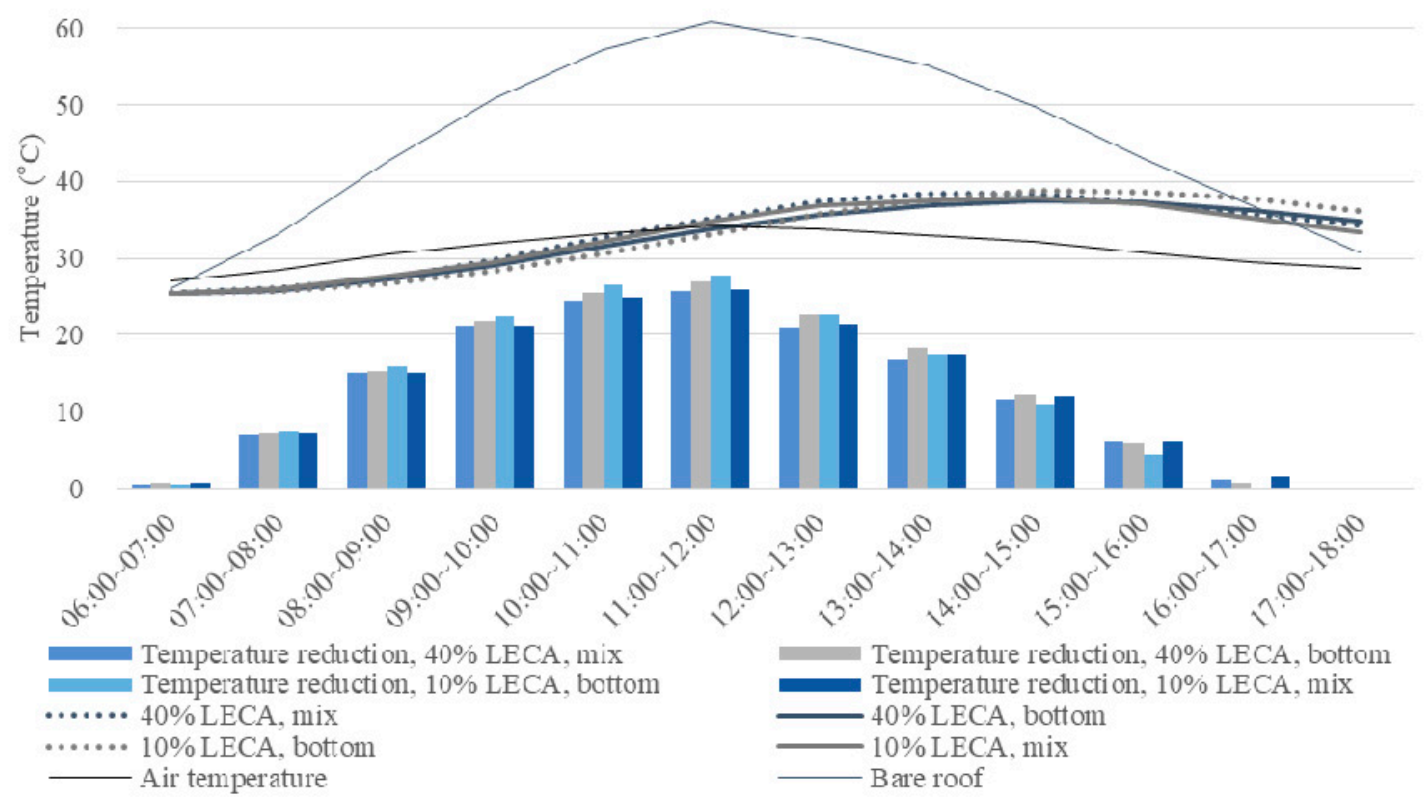

Figure 18. Temperatures and temperature reductions in the cases of the roofs with $10 \%$ and $40 \%$ LECA laid at the bottom with Ipomoea batatas, and of 10\% and 40\% LECA mixed with the soil with Ipomoea batatas (1 October 2017 06:07:57-1 October 2017 17:57:57).

The addition of the Ipomoea batatas layer caused additional evaporation and absorption effects on the growth medium layer as well as reflective, photosynthetic, shielding, shading, and evapotranspiration effects on the Ipomoea batatas layer as a result of irrigation. Our findings demonstrated that the planting of Ipomoea batatas contributed to additional and significant reductions in the rooftop surface temperature by $5-7{ }^{\circ} \mathrm{C}$ when results from the third and fourth stages were compared under slightly different average ambient temperatures $\left(32.08^{\circ} \mathrm{C}\right.$ in the third stage and $32.04^{\circ} \mathrm{C}$ in the fourth stage). The roof with $10 \%$ LECA laid at the bottom and with plants (1 October 2017 07:00-14:00, $19.73{ }^{\circ} \mathrm{C}$ average temperature reduction of the bare rooftop) helped to reduce the average temperature of the bare rooftop by an additional $5.91{ }^{\circ} \mathrm{C}$ than the roof with $10 \%$ LECA laid at the bottom and without plants (24 September 2017 07:00-14:00, $13.82^{\circ} \mathrm{C}$ ); the roof with 10\% LECA mixed with the soil and with plants (same period, $18.73{ }^{\circ} \mathrm{C}$ ) helped to reduce the average temperature of the bare rooftop by an additional $4.81^{\circ} \mathrm{C}$ more than the roof with $10 \%$ LECA mixed with the soil and without plants (same period, $13.92{ }^{\circ} \mathrm{C}$ ); the roof with $40 \%$ LECA laid at the bottom and with plants (same period, $19.37^{\circ} \mathrm{C}$ ) helped to reduce the average temperature of the bare rooftop by an additional $6.49^{\circ} \mathrm{C}$ more than the roof with $40 \%$ LECA laid at the bottom and without plants (same period, $12.88^{\circ} \mathrm{C}$ ); the roof with $40 \%$ LECA mixed with the soil and with plants (same period, $18.44^{\circ} \mathrm{C}$ ) helped to reduce the average temperature of the bare rooftop by an additional $6.93^{\circ} \mathrm{C}$ more than the roof with $40 \%$ LECA mixed with the soil and without plants (same period, $11.51^{\circ} \mathrm{C}$ ). In brief, the roofs with plants could elicit higher passive-cooling effects than roofs without plants.

All four extensive roofs containing different proportions and placements of LECA and plants contributed to stabilizing the temperature of bare rooftop, which in turn mitigate the fluctuation of indoor temperatures and hence increased comfort level in the rooms underneath the roofs. Generally speaking, our experimental results revealed that the roofs with $10 \%$ and $40 \%$ LECA with plants yielded similar reduction in the heat amplitude of the bare rooftop $(64.32 \%-67.11 \%)$ (Table 13, Figure 19). Furthermore, our findings demonstrated that the planting of Ipomoea batatas contributed to additional reduction in the heat amplitude of the bare rooftop by $9.34 \%$ to $17.90 \%$ when the results from the third and fourth stages were compared under slightly different average ambient temperatures $\left(32.08^{\circ} \mathrm{C}\right.$ in the third stage and $32.04{ }^{\circ} \mathrm{C}$ in the fourth stage). In brief, the planting contributed to significant reduction in the heat amplitude of bare rooftop. 
Table 13. Reduction in heat amplitude in the cases of the roofs with $10 \%$ and $40 \%$ LECA laid at the bottom with Ipomoea batata, and of $10 \%$ and $40 \%$ LECA mixed with the soil with Ipomoea batatas (1 October 2017 06:07:57 to 2 October 2017 05:57:57).

\begin{tabular}{|c|c|c|c|c|c|}
\hline & Thermocouple Position & $\begin{array}{c}\text { Average } \\
\text { Temperature } \\
\left({ }^{\circ} \mathrm{C}\right)\end{array}$ & $\begin{array}{c}\text { Range of } \\
\text { Temperature } \\
\left({ }^{\circ} \mathrm{C}\right)\end{array}$ & $\begin{array}{c}\text { Difference in } \\
\text { Temperature } \\
\left({ }^{\circ} \mathrm{C}\right)\end{array}$ & $\begin{array}{c}\text { Heat } \\
\text { Amplitude } \\
\text { Reduction }\end{array}$ \\
\hline & In the air & 29.30 & $26.26-34.41$ & 8.15 & - \\
\hline & Bare rooftop surface & 35.77 & $24.29-61.90$ & 37.61 & - \\
\hline \multirow{4}{*}{ At the bottom } & $10 \%$ LECA, bottom, with plants & 30.89 & $25.48-38.90$ & 13.42 & $64.32 \%$ \\
\hline & 10\% LECA, mix, with plants & 30.36 & $25.36-37.87$ & 12.51 & $66.74 \%$ \\
\hline & $40 \%$ LECA, bottom, with plants & 30.51 & $25.28-37.65$ & 12.37 & $67.11 \%$ \\
\hline & 40\% LECA, mix, with plants & 30.81 & $25.55-38.64$ & 13.09 & $65.20 \%$ \\
\hline
\end{tabular}

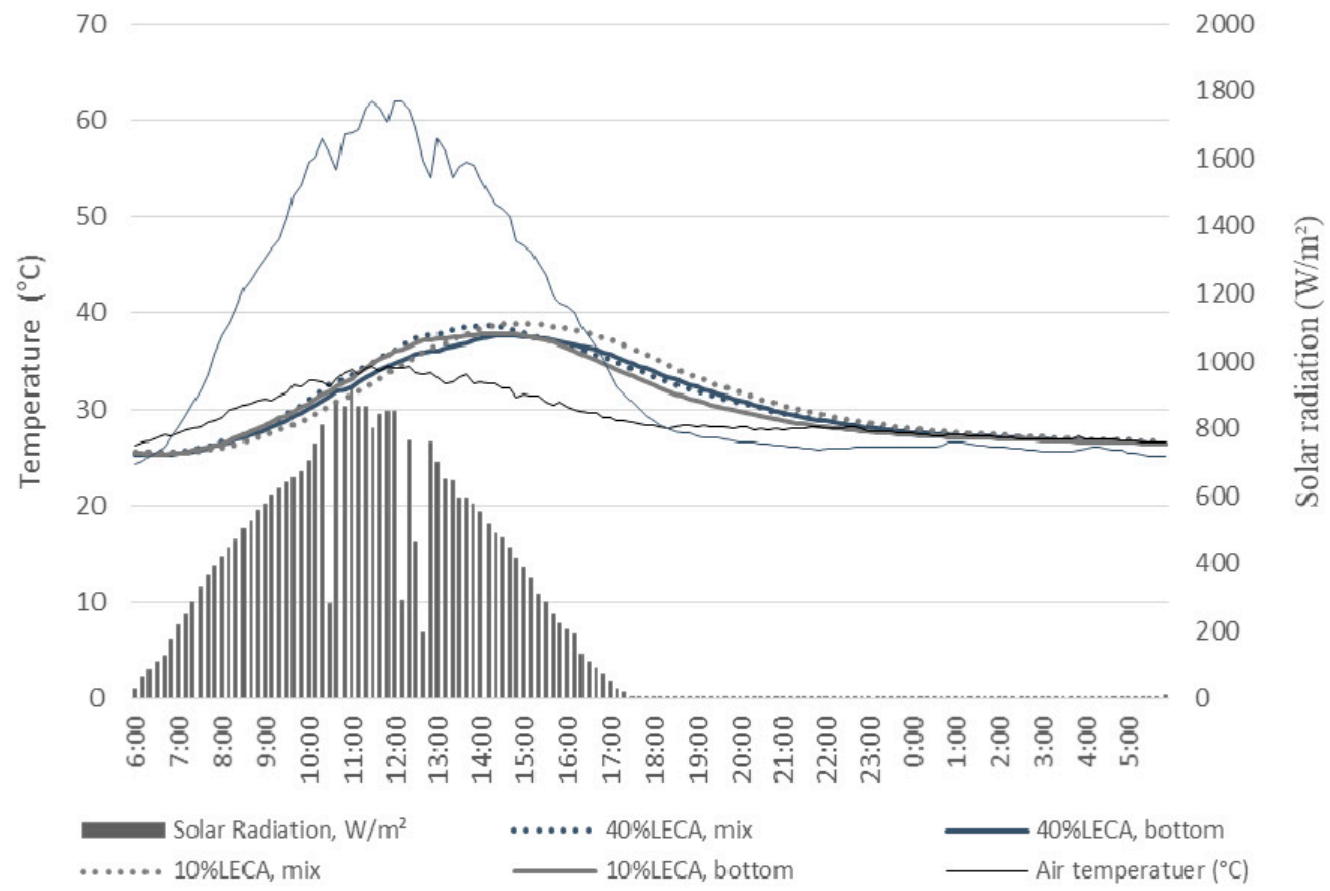

Figure 19. Temperatures and solar radiation in the cases of roofs with $10 \%$ and $40 \%$ LECA laid at the bottom with Ipomoea batata, and of 10\% and 40\% LECA mixed with the soil with Ipomoea batatas (1 October 2017 06:07:57 to 2 October 2017 05:57:57).

Table 14 presents the information we collected regarding treatments, average air temperatures, and average rooftop temperature reductions for the purpose of conveniently comparing four stages to draw the most important conclusions from the details in each stage. In summary, the findings from the four stages demonstrated that, first, under slightly different average air temperature $\left(0.56^{\circ} \mathrm{C}\right.$; i.e., $32.04{ }^{\circ} \mathrm{C}$ minus $31.48{ }^{\circ} \mathrm{C}$ ), the combined effects of LECA and Ipomoea batata significantly reduced the average temperature of the bare rooftop by an additional $10.19{ }^{\circ} \mathrm{C}$, or $106.81 \%$, as can be seen by the additional bare-rooftop temperature reduction from $9.54{ }^{\circ} \mathrm{C}(0 \%$ LECA without plants in the second stage) to $19.73{ }^{\circ} \mathrm{C}$ (10\% LECA with plants in the fourth stage). Second, at slightly different air temperatures, Ipomoea batata further reduced the average temperature of the bare rooftop from 4.81 to $6.93{ }^{\circ} \mathrm{C}$ (based on the results from the third and fourth stages), whereas the $10 \%-40 \%$ LECA could only further reduce the average temperature of the bare rooftop from 0.4 to $1.03{ }^{\circ} \mathrm{C}$ (based on the results from the second stage). Nevertheless, because the unit weight of the roof with $0 \%$ LECA (conventional garden soil) after irrigation would have reached $135.95 \mathrm{~kg} / \mathrm{m}^{2}$ (Table 15), which would exceed the designed live load of $200 \mathrm{~kg} / \mathrm{m}^{2}$ if an adult with a normal weight $(60 \mathrm{~kg})$ was introduced, using LECA to partly replace the conventional garden soil is highly recommended. 
Table 14. Comparisons of the passive-cooling effects for four stages.

\begin{tabular}{|c|c|c|c|c|}
\hline Stage & Treatment & $\begin{array}{c}\text { Average Air } \\
\text { Temperature }\left({ }^{\circ} \mathrm{C}\right)\end{array}$ & $\begin{array}{l}\text { Average Rooftop } \\
\text { Temperature Reduction } \\
\left({ }^{\circ} \mathrm{C}\right)\end{array}$ & Conclusions \\
\hline \multirow{4}{*}{ First stage } & $0 \%$ LECA, $10 \mathrm{~cm}$ & \multirow{4}{*}{29.18} & 11.45 & \multirow{4}{*}{$\begin{array}{l}\text { - Although the } 0 \% \text { LECA roof with the growth-medium depth of } 25 \mathrm{~cm} \text { demonstrated the greatest } \\
\text { passive-cooling effect, the } 0 \% \text { LECA roof with a growth-medium depth of } 10 \mathrm{~cm} \text {, in yielding the } \\
\text { highest marginal temperature reduction, demonstrated the most efficient passive-cooling effect. }\end{array}$} \\
\hline & $0 \%$ LECA, $15 \mathrm{~cm}$ & & 12.82 & \\
\hline & $0 \%$ LECA, $20 \mathrm{~cm}$ & & 14.19 & \\
\hline & $0 \%$ LECA, $25 \mathrm{~cm}$ & & 14.46 & \\
\hline \multirow{4}{*}{ Second stage } & $\begin{array}{l}0 \% \text { LECA, } 10 \mathrm{~cm} \text {, } \\
\text { bottom, no plant }\end{array}$ & \multirow{4}{*}{31.48} & 9.54 & \multirow{4}{*}{$\begin{array}{l}\left.\text { - The roofs with } 10 \% \text { and } 40 \% \text { LECA had slightly greater passive-cooling effects (by } 0.4-1.03^{\circ} \mathrm{C}\right) \text { than } \\
\text { did the roof with } 0 \% \text { LECA. } \\
\left.\text { - The roof with } 10 \% \text { LECA had a slightly greater passive-cooling effect (by } 0.63^{\circ} \mathrm{C}\right) \text { than did the roof } \\
\text { with } 40 \% \text { LECA. }\end{array}$} \\
\hline & $\begin{array}{l}10 \% \text { LECA, } 10 \mathrm{~cm} \text {, } \\
\text { bottom, no plant }\end{array}$ & & 10.57 & \\
\hline & $\begin{array}{l}40 \% \text { LECA, } 10 \mathrm{~cm} \text {, } \\
\text { bottom, no plant }\end{array}$ & & 9.94 & \\
\hline & $\begin{array}{l}70 \% \text { LECA, } 10 \mathrm{~cm} \text {, } \\
\text { bottom, no plant }\end{array}$ & & 6.84 & \\
\hline \multirow{4}{*}{ Third stage } & $\begin{array}{l}10 \% \text { LECA, } 10 \mathrm{~cm}, \\
\text { bottom, no plant }\end{array}$ & \multirow{4}{*}{32.08} & 13.82 & \multirow{4}{*}{$\begin{array}{l}\text { - Comparing the results for the second, third and fourth stages, the roofs with } 10 \% \text { LECA, regardless of } \\
\text { whether the LECA was laid at the bottom or mixed with the soil, demonstrated slightly greater } \\
\text { passive-cooling effects than did roofs with } 40 \% \text { LECA. } \\
\text { Without plants (second and third stages), the roofs with } 10 \% \text { LECA slightly reduced the average } \\
\text { temperature of the bare rooftop by an additional } 0.63-2.41{ }^{\circ} \mathrm{C} \text { more than roofs with } 40 \% \text { LECA. } \\
\text { With plants (fourth stage), the roofs with } 10 \% \text { LECA slightly reduce the average temperature of the } \\
\text { bare rooftop by an additional } 0.31-0.35^{\circ} \mathrm{C} \text { more than roofs with } 40 \% \text { LECA. }\end{array}$} \\
\hline & $\begin{array}{l}10 \% \text { LECA, } 10 \mathrm{~cm}, \\
\text { mixed, no plant }\end{array}$ & & 13.92 & \\
\hline & $\begin{array}{l}40 \% \text { LECA, } 10 \mathrm{~cm} \text {, } \\
\text { bottom, no plant }\end{array}$ & & 12.88 & \\
\hline & $\begin{array}{l}40 \% \text { LECA, } 10 \mathrm{~cm} \text {, } \\
\text { mixed, no plant }\end{array}$ & & 11.51 & \\
\hline \multirow{4}{*}{ Fourth stage } & $\begin{array}{c}10 \% \text { LECA, } 10 \mathrm{~cm} \text {, } \\
\text { bottom, with plants }\end{array}$ & \multirow{4}{*}{32.04} & 19.73 & \multirow{4}{*}{$\begin{array}{l}\text { - At slightly different average air temperatures }\left(0.04^{\circ} \mathrm{C}\right), 32.08^{\circ} \mathrm{C} \text { in the third stage versus } 32.04^{\circ} \mathrm{C} \text { in } \\
\text { the fourth stage, planting helped to significantly reduce the average temperature of the bare rooftop } \\
\text { by an additional } 4.81-6.93^{\circ} \mathrm{C} \text {. } \\
\text { - At slightly different average air temperatures }\left(0.56^{\circ} \mathrm{C}\right), 31.48^{\circ} \mathrm{C} \text { in the second stage versus } 32.04^{\circ} \mathrm{C} \\
\text { in the fourth stage, the combined effects of } 10 \% \mathrm{LECA} \text { and plants helped to significantly reduce the } \\
\text { average temperature of the bare rooftop by an additional } 10.19^{\circ} \mathrm{C}\left(19.73^{\circ} \mathrm{C} \text { minus } 9.544^{\circ} \mathrm{C}\right) \text {. }\end{array}$} \\
\hline & $\begin{array}{l}10 \% \text { LECA, } 10 \mathrm{~cm} \text {, } \\
\text { mixed, with plants }\end{array}$ & & 18.73 & \\
\hline & $\begin{array}{l}40 \% \text { LECA, } 10 \mathrm{~cm} \text {, } \\
\text { bottom, with plants }\end{array}$ & & 19.37 & \\
\hline & $\begin{array}{l}40 \% \text { LECA, } 10 \mathrm{~cm} \text {, } \\
\text { mixed, with plants }\end{array}$ & & 18.44 & \\
\hline
\end{tabular}

Note: The dates selected for the first, second, third, and fourth stages were 14 May 2017, 25 July 2017, 24 September 2017 and 1 October 2017, respectively. To standardize the temperature calculations for comparison across stages, the time slot selected for calculating the "average air temperature" and the "average rooftop temperature reduction" was from 07:00 to 14:00 on the same day for all four stages. The depth of the growth medium was $10 \mathrm{~cm}$ for the second, third, and fourth stages. 
Table 15. Cost-benefit analysis of the LECA extensive roofs.

\begin{tabular}{|c|c|c|c|c|c|c|c|c|c|}
\hline $\begin{array}{l}\text { The Roofs with LECA } \\
\text { Laid at the Bottom and } \\
\text { Without Plants } \\
\text { (Decision) }\end{array}$ & $\begin{array}{c}\text { Unit Weight of } \\
\text { Growth Medium } \\
\text { Before Irrigation } \\
\left(\mathrm{kg} / \mathrm{m}^{2}\right)\end{array}$ & $\begin{array}{l}\text { Unit Weight of } \\
\text { Growth Medium } \\
\text { after Irrigation } \\
\left(\mathrm{kg} / \mathrm{m}^{2}\right)\end{array}$ & $\begin{array}{c}\text { Saturated } \\
\text { Water Weight } \\
\quad(\mathrm{kg})\end{array}$ & $\begin{array}{l}\text { Estimated } \\
\text { Unit Cost } \\
\text { (\$US } \\
\text { Dollars/m²) }\end{array}$ & $\begin{array}{c}\text { Total Weight before } \\
\text { Irrigation }(\mathrm{kg}) \\
\text { (per Unit Building, Green } \\
\text { Roof Area } 42 \mathrm{~m}^{2} \text { or } 452 \mathrm{ft}^{2} \text { ) }\end{array}$ & $\begin{array}{c}\text { Total Weight after } \\
\text { Irrigation }(\mathrm{kg}) \\
\text { (per Unit Building, Green } \\
\text { Roof Area } 42 \mathrm{~m}^{2} \text { or } 452 \mathrm{ft}^{2} \text { ) }\end{array}$ & $\begin{array}{l}\text { Estimated Total Cost } \\
\text { of Growth Medium } \\
\text { per Unit Building } \\
\text { (\$US dollar) }\end{array}$ & $\begin{array}{l}\text { Average Rooftop } \\
\text { Temperature } \\
\text { Reduction }\left({ }^{\circ} \mathrm{C}\right)\end{array}$ & $\begin{array}{l}\text { Heat } \\
\text { Amplitude } \\
\text { Reduction } \\
(\%)\end{array}$ \\
\hline $\begin{array}{c}0 \% \text { LECA roof, } \\
\text { (benchmark) }\end{array}$ & 81.27 & 135.95 & 54.68 & 21.67 & 3413.34 & 5709.90 & 910.14 & 9.54 & 63.03 \\
\hline $\begin{array}{l}\text { 10\% LECA roof } \\
\text { (preferred) }\end{array}$ & 76.71 & 126.38 & 49.67 & 23.07 & $\begin{array}{c}3221.82 \\
\text { (cut by } 191.52 \mathrm{~kg}, 5.6 \% \\
\text { 3 adults) }\end{array}$ & $\begin{array}{c}5307.96 \\
\text { (cut by } 401.94 \mathrm{~kg}, 7.0 \% \text {, } \\
7 \text { adults) }\end{array}$ & $\begin{array}{c}968.94 \\
\text { (US\$58.8 more) }\end{array}$ & 10.57 & 61.91 \\
\hline $\begin{array}{l}40 \% \text { LECA roof } \\
\text { (preferred) }\end{array}$ & 63.02 & 97.69 & 34.67 & 27.26 & $\begin{array}{c}2646.84 \\
\text { (cut by } 766.50 \mathrm{~kg}, 22.5 \%, \\
13 \text { adults) }\end{array}$ & $\begin{array}{c}4102.98 \\
\text { (cut by } 1606.92 \mathrm{~kg}, 28.1 \% \text {, } \\
27 \text { adults) }\end{array}$ & $\begin{array}{c}1144.92 \\
\text { (US\$234.8 more) }\end{array}$ & 9.94 & 58.47 \\
\hline $\begin{array}{c}70 \% \text { LECA roof } \\
\text { (not preferred) }\end{array}$ & 49.32 & 69.00 & 19.68 & 31.44 & 2071.44 & 2898.00 & 1320.48 & 6.84 & 53.40 \\
\hline
\end{tabular}

Note: Because soil costs New Taiwan (NT) \$200 (US\$6.67) per bag (25.0 kg or 55.1 lbs.), soil costs NT\$0.008/g. Because LECA costs NT\$360 (US\$12) per bag (12 kg or 26.5 lbs.), LECA costs NT $\$ 0.03 / \mathrm{g}$. The average rooftop area of a residential townhouse in Taiwan is approximately $60.0 \mathrm{~m}^{2}(\mathrm{~L} \times \mathrm{W}=15 \mathrm{~m} \times 4 \mathrm{~m})$ or $645.5 \mathrm{ft}^{2}$. Given that the average surface area of a set of stairs is approximately $9 \mathrm{~m}^{2}$ or $96.8 \mathrm{ft}^{2}$ and the average surface area of a path on a bare rooftop is approximately $9 \mathrm{~m}^{2}(\mathrm{~L} \times \mathrm{W}=15 \mathrm{~m} \times 0.6 \mathrm{~m})$, the surface area of a green-roof system is approximately $42 \mathrm{~m}^{2}\left(60 \mathrm{~m}^{2}-9 \mathrm{~m}^{2}-9 \mathrm{~m}^{2}\right)$ or $452 \mathrm{ft}^{2}$ per unit building. NT $\$$ to US $\$=30: 1 . \mathrm{m}^{2}$ to $\mathrm{ft}^{2}=1: 10.758$. $\mathrm{kg}$ to lbs $=1: 2.205$. The time slot selected to calculate the "average rooftop temperature reduction" was from 07:00 to 14:00 of the same day. 


\subsection{Weight-Reduction-and-Cost Analysis of the Extensive Roofs Containing LECA}

According to the results of the weight-reduction-and-cost analysis (Table 15), the growth medium alone constantly yields a weight load of $135.95 \mathrm{~kg} / \mathrm{m}^{2}$ on the rooftop structure when the roof with $0 \%$ LECA (conventional garden soil) is applied after irrigation in $100 \%$ saturation. By further including the weight loads of other supplementary structures-the filter fabric, the drainage layer, the root barrier, and the supporting racks, for example-of the extensive roof system, the total weight load can easily exceed the designed live load of $200 \mathrm{~kg} / \mathrm{m}^{2}$ if an adult is introduced. As a result, an extensive roof system with lightweight growth medium is preferred and needed. Based on the results obtained in the second stage, the roofs designed with $10 \%$ or $40 \%$ LECA were revealed to be not only lighter than those without LECA but also to provide a slightly additional passive-cooling effect for the bare rooftop. Compared with the roof with 0\% LECA, the roof with 10\% LECA laid at the bottom-despite costing an additional US\$58.8 dollars per unit building — can slightly reduce the average temperature of the bare rooftop by additional $1.03^{\circ} \mathrm{C}$ (from 9.54 to $10.57^{\circ} \mathrm{C}$ ) and alleviate the weight load on the building structure by $191.52 \mathrm{~kg}$ or $422.30 \mathrm{lbs}$. (equivalent to 3 adults, assumed 1 adult equaling $60.00 \mathrm{~kg}$ or $132.30 \mathrm{lbs}$.) and $401.94 \mathrm{~kg}$ or $886.28 \mathrm{lbs}$. (7 adults) before and after irrigation, respectively. Compared with the roof with $0 \%$ LECA, the roof with $40 \%$ LECA — despite costing an additional US $\$ 234.8$ dollars per unit building — can slightly reduce the temperature of the bare rooftop by additional $0.40{ }^{\circ} \mathrm{C}$ (from 9.54 to $9.94{ }^{\circ} \mathrm{C}$ ) and significantly reduce the weight load on the building structure by $766.50 \mathrm{~kg}$ or $1690.13 \mathrm{lbs}$. (13 adults) and $1606.92 \mathrm{~kg}$ or $3543.26 \mathrm{lbs}$. (27 adults) before and after irrigation, respectively. If brief, although the additional thermal reduction in the bare rooftop in the roofs with $10 \%-40 \%$ LECA was not as high as one might expect, the greatest contribution of the LECA roofs was the increase in building safety resulting from the alleviation of the constant weight load to which the building structure is subjected.

\section{Conclusions}

Stressful lifestyles compel humans to seek temporary retreats. Both gazing at natural landscapes and participating in agricultural activities can help to reduce stress, promote positive mood and psychophysiological restoration, and improve mental health. Because most buildings, in an effort to reduce construction costs, are designed only to meet minimum legal requirements for structural live load, the development of lightweight growth mediums for the extensive green-roof systems is needed. Whether lighter green roof systems can be developed to yield superior thermal performance and to serve as food sources for a city lacking agricultural sites and temporary retreat sites is a question of interest. In this paper, we demonstrated that, at a slightly different average air temperature $\left(0.56^{\circ} \mathrm{C}\right)$, the combined effects of LECA and the planting of Ipomoea batatas helped to significantly reduce the average temperature of the bare rooftop by an additional $10.19^{\circ} \mathrm{C}$ (from $9.54{ }^{\circ} \mathrm{C}$ to $19.73^{\circ} \mathrm{C}$ ) compared with the temperature of the roof with conventional garden soil of the same depth $(10 \mathrm{~cm})$ and without plants. Our key conclusions are as follows:

- Because of the evapotranspiration, shading, shielding, reflective, and photosynthetic effects of the vegetation layer, the roofs with Ipomoea batata exhibited significantly higher passive-cooling effects than did the roofs without Ipomoea batata.

- Because of the air pockets inside and between particles in LECA, the roofs with $10 \%$ and $40 \%$ LECA had slightly greater passive-cooling effects than did the roofs with $0 \%$ LECA (conventional garden soil).

- At a slightly different average air temperature $\left(0.56{ }^{\circ} \mathrm{C}\right.$; i.e., $32.04^{\circ} \mathrm{C}$ minus $\left.31.48^{\circ} \mathrm{C}\right)$, the combined effects of LECA and Ipomoea batata helped to significantly reduce the average temperature of the bare rooftop by an additional $10.19^{\circ} \mathrm{C}$, or by $106.81 \%$ (temperature reduction of the bare rooftop increased from $9.54{ }^{\circ} \mathrm{C}$ in $0 \%$ LECA without plants in the second stage to $19.73{ }^{\circ} \mathrm{C}$ in $10 \%$ LECA with plants in the fourth stage). 
- LECA reduces the effect of heat-amplitude reduction, whereas Ipomoea batata helps to strengthen this effect. The roofs with 10-40\% LECA and Ipomoea batata helped to reduce the heat amplitude of the bare rooftop by approximately $65 \%$.

- Although the $40 \%$ and $10 \%$ LECA roofs in the second stage demonstrated a similar performance in reducing the temperature of the bare rooftop (only different by $0.63^{\circ} \mathrm{C}$ ), after irrigation, the roofs with $40 \%$ and 10\% LECA were able to reduce the weight load by $1606.92 \mathrm{~kg}$ (3543.26 lbs, 27 adults) and $401.94 \mathrm{~kg}$ ( $886.28 \mathrm{lbs}, 7$ adults) per unit building, respectively.

In summary, compared with the use of roofs with the conventional garden soil and containing no LECA and no plants of the same depth $(10 \mathrm{~cm})$, we recommend the use of roofs with $40 \%$ LECA and Ipomoea batata to achieve significant temperature reductions in bare rooftop, alleviating the weight load of building structures and providing a nutritious, low-maintenance, and year-round food supply. In the future, we suggest comparing thermal performance in absolute terms by simultaneously arranging the experimental blocks with and without plants when more equipment becomes available. Second, because it was the plant material rather than LECA that helped to elicit significant passive-cooling effects in the bare rooftops and reduce the carbon dioxide emissions resulting from transporting food from farm to table, we suggest that in the future more species of vegetables be explored for their adaptability on rooftops and passive-cooling performances in extensive green-roof systems. Third, we also suggest other lightweight growth mediums be explored for their potential thermal performance in reducing the temperature and heat amplitude of the bare rooftops.

Author Contributions: Conceptualization, Y.-Y.H.; Methodology, Y.-Y.H.; Software, T.-J.M.; Validation, Y.-Y.H.; Formal Analysis, Y.-Y.H.; Investigation, T.-J.M.; Resources, Y.-Y.H.; Data Curation, Y.-Y.H.; Writing-Original Draft Preparation, Y.-Y.H.; Writing-Review \& Editing, Y.-Y.H.; Visualization, T.-J.M.; Supervision, Y.-Y.H.; Project Administration, Y.-Y.H.; Funding Acquisition, Y.-Y.H.

Funding: This research received no external funding.

Acknowledgments: The authors express their sincere thanks to Yen-Chi Tsai for preparing Figure 4, Figure 8, Figure 12, and Figure 16. The authors also thanks Department of Landscape Architecture and Wen-Tsan Liu for providing experiment equipment.

Conflicts of Interest: The authors declare no conflict of interest.

\section{References}

1. Frumkin, H. Beyond toxicity: Human health and the natural environment. Am. J. Prev. Med. 2001, 20, 234-240. [CrossRef]

2. McEwen, B.S. Protective and damaging effects of stress mediators. N. Engl. J. Med. 1998, 338, 171-179. [CrossRef] [PubMed]

3. Sluiter, J.K.; Frings-Dresen, M.H.W.; Meijman, T.F.; van der Beek, A.J. Reactivity and recovery from different types of work measured by catechol amines and cortisol: A systematic literature overview. J. Occup. Environ. Med. 2000, 57, 298-315. [CrossRef]

4. Kaplan, R. Some psychological benefits of gardening. Environ. Behav. 1973, 5, 145-162. [CrossRef]

5. Ulrich, R.S. Visual landscapes and psychological well-being. Landsc. Res. 1979, 4, 17-23. [CrossRef]

6. Hartig, T.; Book, A.; Garvill, J.; Olsson, T.; Garlilng, T. Environmental influences on psychological restoration. Scand. J. Psychol. 1995, 37, 378-393. [CrossRef]

7. Ulrich, R.S.; Simons, R.F.; Losito, B.D.; Fiorito, E.; Miles, M.A.; Zelson, M. Stress recovery during exposure to natural and urban environments. J. Environ. Psychol. 1991, 11, 201-230. [CrossRef]

8. Van den Berg, A.; Koole, S.L.; Van der Wulp, N.Y. Environmental preference and restoration: (How) are they related? J. Environ. Psychol. 2003, 23, 135-146. [CrossRef]

9. Heliker, D.; Chadwick, A.; O'Connell, T. The meaning of gardening and the effects on perceived well being of a gardening project on diverse populations of elders. Act. Adapt. Aging 2000, 24, 35-56. [CrossRef]

10. Liu, T.C.; Shyu, G.S.; Fang, W.T.; Liu, S.Y.; Cheng, B.Y. Drought tolerance and thermal effect measurements for plants suitable for extensive green roof planting in humid subtropical climates. Energy Build. 2012, 47, 180-188. [CrossRef] 
11. Karachaliou, P.; Santamouris, M.; Pangalou, H. Experimental and numerical analysis of the energy performance of a large scale intensive green roof system installed on an office building in Athens. Energy Build. 2016, 114, 256-264. [CrossRef]

12. Peng, L.L.H.; Jim, C.Y. Green-roof effects on neighborhood microclimate and human thermal sensation. Energies 2013, 6, 589-618. [CrossRef]

13. Abuseif, M.; Gou, Z. A review of roofing methods: Construction, features, heat reduction, payback period and climatic responsiveness. Energies 2018, 11, 3196. [CrossRef]

14. My Garden. Family Farm; My House Publishing: Taipei, Taiwan, 2011.

15. Construction and Planning Agency. Ministry of the Interior, Architectural Regulations: Weight Load Section. Available online: http:/ /w3.cpami.gov.tw/law/law/lawe-2/b-rule.htm/ (accessed on 14 October 2017).

16. Dunnett, N.; Nolan, A. The effect of substrate depth and supplementary watering on the growth of nine herbaceous perennials in a semi-extensive green roof. Acta Hortic. 2004, 643, 305-309. [CrossRef]

17. Papafotiou, M.; Pergialioti, N.; Tassoula, L. Growth of native Aromatic Xerophytes in an extensive Mediterranean green roof as affected by substrate type and depth and irrigation frequency. HortScience 2013, 48, 1327-1333.

18. Kotsiris, G.; Nektarios, P.A.; Paraskevopoulou, A.T. Lavandula angustisfolia growth and physiology is affected by substrate type and depth when grown under Mediterranean semi-intensive green roof conditions. HortScience 2012, 47, 311-317.

19. Nektarios, P.A.; Amountzias, L.; Kokkinou, I.; Ntoulas, N. Green roof substrate type and depth affect the growth of the native species Dianthus fruticosus under reduced irrigation regimens. HortScience 2011, 46, 1208-1216.

20. Ntoulas, N.; Kektarios, P.A.; Spaneas, K.; Kadoglou, N. Semi-extensive green roof substrate type and depth effects on Zoysia matrella "Zeon" growth and drought tolerance under different irrigation regimes. Acta Agric. Scand. Sect. B-Soil Plant Sci. 2012, 62 (Suppl. 1), 165-173. [CrossRef]

21. Kotsirisa, G.; Nektariosa, P.A.; Ntoulasa, N.; Kargasb, G. An adaptive approach to intensive green roofs in the Mediterranean climate region. Urban Urban Gree 2013, 12, 380-392. [CrossRef]

22. Lin, Y.J.; Lin, H.T. Thermal performance of different planting substrates and irrigation frequencies in extensive tropical rooftop greeneries. Build. Environ. 2011, 46, 345-355. [CrossRef]

23. Wanphen, S.; Nagano, K. Experimental study of the performance of porous materials to moderate the roof surface temperature by its evaporative cooling effect. Build. Environ. 2009, 44, 338-351. [CrossRef]

24. Sutcu, M. Influence of expanded vermiculite on physical properties and thermal conductivity of clay bricks. Ceram. Int. 2015, 41, 2819-2827. [CrossRef]

25. Central Weather Bureau. Climate Statistics for Temperature. Available online: http:/ / e-service.cwb.gov.tw/ HistoryDataQuery/index.jsp/ (accessed on 31 October 2017).

26. Boudaghpour, S.; Hashemi, S. A study on light expended clay aggregate (LECA) in a Geotechnical view and its application on greenhouse and greenroof cultivation. Int. J. Geol. 2008, 4, 59-63.

27. Mun, K.J. Development and tests of lightweight aggregate using sewage sludge for nonstructural concrete. Constr. Build. Mater. 2007, 21, 1583-1588. [CrossRef]

28. Arioz, O.; Kilinc, K.; Karasu, B.; Kaya, G.; Arslan, G.; Tuncan, M.; Tuncan, A.; Korkut, M.; Kivrak, S. A preliminary research on the properties of lightweight expanded clay aggregate. J. Aust. Ceram. Soc. 2008, $44,23-30$.

29. Sales, A.; Souza, F.R.; Santos, W.N.; Zimer, A.M.; Almeida, F.C.R. Lightweight composite concrete produced with water treatment sludge and sawdust: Thermal properties and potential application. Constr. Build. Mater. 2010, 24, 2446-2453. [CrossRef]

30. Zhang, B.; Poon, C.S. Use of furnace ash for producing lightweight aggregate concrete with thermal insulation properties. J. Clean. Prod. 2015, 99, 94-100. [CrossRef]

31. Song, U.; Kim, E.; Bang, J.H.; Son, D.J.; Waldman, B.; Lee, E.L. Wetlands are an effective green roof system. Build. Environ. 2013, 66, 141-147. [CrossRef]

32. Huang, Y.Y.; Chen, C.T.; Tsai, Y.C. Reduction of temperatures and temperature fluctuations by hydroponic green roofs in a subtropical urban climate. Energy Build. 2016, 129, 174-185. [CrossRef]

33. He, Y.; Yu, H.; Dong, N.; Ye, H. Thermal and energy performance assessment of extensive green roof in summer: A case study of a lightweight building in Shanghai. Energy Build. 2016, 127, 762-773. [CrossRef]

34. Jaffal, I.; Ouldboukhitine, S.E.; Belarbi, R. A comprehensive study of the impact of green roofs on building energy performance. Renew. Energy 2012, 43, 157-164. [CrossRef] 
35. Jim, C.Y.; Peng, L.L.H. Weather effect on thermal and energy performance of an extensive tropical green roof. Urban Urban Gree 2012, 11, 73-85. [CrossRef]

36. Wong, N.H.; Tan, P.Y.; Chen, Y. Study of thermal performance of extensive rooftop greenery systems in the tropical climate. Build. Environ. 2007, 42, 25-54. [CrossRef]

(C) 2019 by the authors. Licensee MDPI, Basel, Switzerland. This article is an open access article distributed under the terms and conditions of the Creative Commons Attribution (CC BY) license (http:/ / creativecommons.org/licenses/by/4.0/). 